Article

\title{
Toward a Distinct and Quantitative Validation Method for Predictive Process Modelling-On the Example of Solid-Liquid Extraction Processes of Complex Plant Extracts
}

\author{
Maximilian Sixt, Lukas Uhlenbrock and Jochen Strube * \\ Institute for Separation and Process Technology, Clausthal University of Technology, 38678 Clausthal-Zellerfeld, \\ Germany; sixt@itv.tu-clausthal.de (M.S.); uhlenbrock@itv.tu-clausthal.de (L.U.) \\ * Correspondence: strube@itv.tu-clausthal.de
}

Received: 2 May 2018; Accepted: 23 May 2018; Published: 1 June 2018

check for updates

\begin{abstract}
Physico-chemical modelling and predictive simulation are becoming key for modern process engineering. Rigorous models rely on the separation of different effects (e.g., fluid dynamics, kinetics, mass transfer) by distinct experimental parameter determination on lab-scale. The equations allow the transfer of the lab-scale data to any desired scale, if characteristic numbers like e.g., Reynolds, Péclet, Sherwood, Schmidt remain constant and fluid-dynamics of both scales are known and can be described by the model. A useful model has to be accurate and therefore match the experimental data at different scales and combinations of process and operating parameters. Besides accuracy as one quality attribute for the modelling depth, model precision also has to be evaluated. Model precision is considered as the combination of modelling depth and the influence of experimental errors in model parameter determination on the simulation results. A model is considered appropriate if the deviation of the simulation results is in the same order of magnitude as the reproducibility of the experimental data to be substituted by the simulation. Especially in natural product extraction, the accuracy of the modelling approach can be shown through various studies including different feedstocks and scales, as well as process and operating parameters. Therefore, a statistics-based quantitative method for the assessment of model precision is derived and discussed in detail in this paper to complete the process engineering toolbox. Therefore a systematic workflow including decision criteria is provided.
\end{abstract}

Keywords: process model validation; partial least square regression; phytochemicals; natural extracts

\section{Introduction}

Verification and validation present an issue for different kinds of predictive models applied e.g., in economics and banking [1], climate [2], traffic [3], and not least, of course, in process technology [4-7].

Sargent [5] defines model verification as "ensuring that the program of the model and its implementation are correct" and model validation as "substantiation that a model within its domain of applicability possesses a satisfactory range of accuracy consistent with the intended application of the model" based on [4]. A general procedure, including statistical analysis and quantification of whether a model is valid or not, is still missing in process design and development in chemical and pharmaceutical industries. In most cases, the effort to ensure model validity is the major obstacle for decision makers in industry to expand the use of physico chemical-based predictive process modelling instead of or in addition to experimental data from mini- or pilot-plants. This is the main discussion point regarding modelling in process engineering. This is often a point of dissent between academia and industry in many working groups [8-12]. Academia favors rigorous process modelling as the 
only scientifically sound method for process understanding in combination with laboratory scale experiments for model parameter determination. In contrast, industry avoids the early project efforts in model development due to costs, efforts, and resources. Major obstacle is that no investment decision would be made based on theoretic results without experimental proof. Therefore, any process modelling activity has to prove-distinct and self-explanatory-the model validity a priori.

This study is an attempt to propose a general procedure to assess model validity, based on quantitative decision criteria on the example of an industrial relevant complex component mixture from plants with natural variable feedstock.

There is a need for detailed and precise rigorous process models in chemical engineering because a significant amount of resources in early process development and optimization can be saved. Moreover, predictive models allow evaluation of the process at critical points of operation, e.g., start-up/shut-down, unstable operating points in terms of energy supply and removal and feedstock variations. Especially, feedstock variations are a hot topic in the processing of phyto-pharmaceuticals due to the natural content fluctuations of target molecules in the plants. Besides engineering and economic considerations, especially in the pharmaceutical industry, a modern concept of quality assurance through the whole lifecycle of the product, reaching from early stage of research and development to production, called Quality-by-Design $(\mathrm{QbD})$, gains more and more influence and acceptance and is demanded by authorities [13-15]. The basis of QbD is the evaluation of a so-called design space in which the process is kept while maintaining constant quality attributes of the final product. The establishment of a design space demands multi-parameter optimizations, requiring significant experimental effort. Rigorous process models can contribute significantly by substituting a part of the experiments and therefore, lead from pure empirical process design to a model and data driven process assessment. The process models utilized have to be rigorous (strictly derived from physico-chemistry) in order to be predictive with regard to parameter range and scale. To define a design space, critical quality attributes have to be determined and ranked, first. The principle of the QbD approach is depicted in Figure 1 and discussed in detail in the cited literature [13].

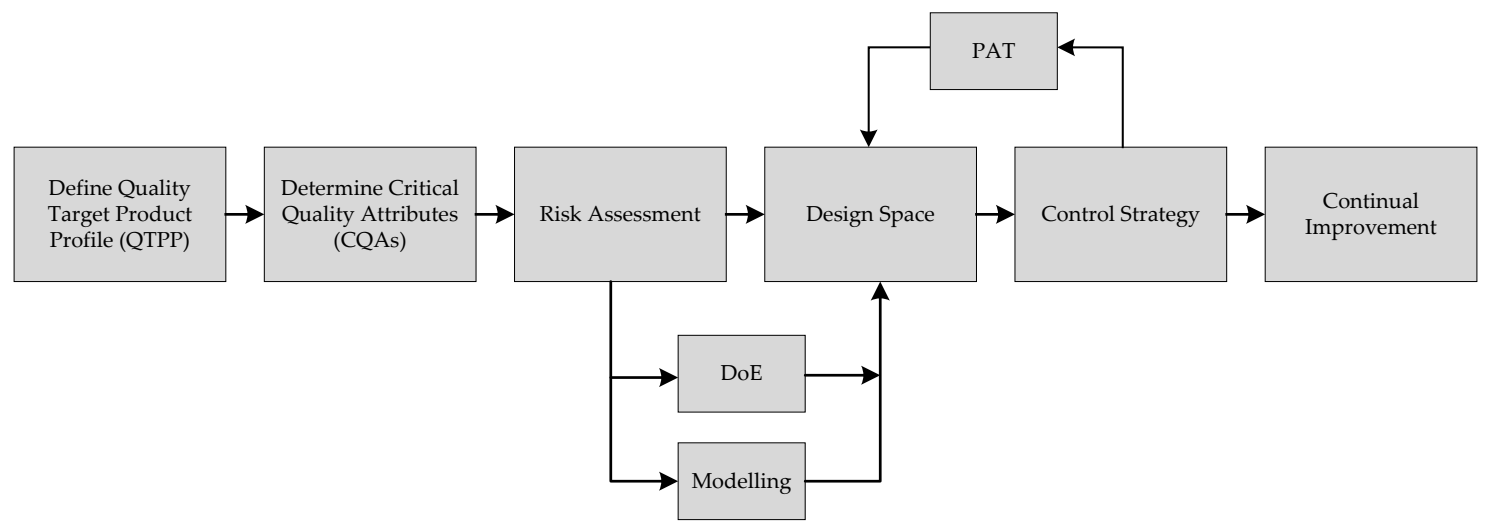

Figure 1. The Quality-by-Design (QbD)-approach to quality assurance [13], PAT process analytical technology, DoE design of experiments.

If the variance of those critical product quality attributes is narrow, a broad and multi-parameter design space is needed, in order to cope appropriately with natural feedstock variability, exemplified by Figure 2.

In contrast, a narrow operation parameter space is sufficient to fulfil the quality requirements, but may cause troubles in manufacturing, if approved in a too small range, due to equipment limitations and breeding success toward high active component content of the used plants. If Quality-by-Design is strictly applied, a reconsideration of the critical quality attributes, the risk assessment, and the derived design space becomes necessary if there is a significant change in the boundary conditions of the process or the production is out of specification for some time and the initial risk assessment did not 
address these issues in an adequate way. This is explicitly in conflict to a stringent approval procedure, submitting of one single point of operation with narrow parameter ranges to the regulatory agencies, as it is historically common practice in phytoextraction.

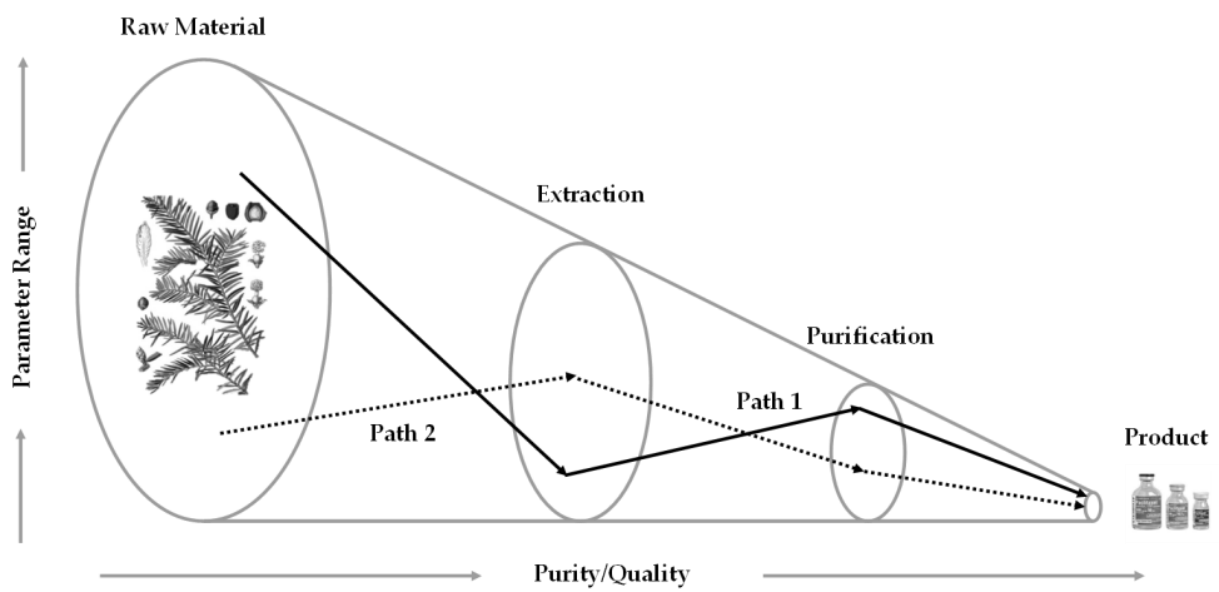

Figure 2. Basic idea of design spaces in phytoextraction [13].

To ensure the proper definition of a design space with the aid of a physico-chemical process model, the model has to fulfil the accuracy and precision criteria. Accuracy is the ability to predict the experimental data correctly within a whole set of parameters. In case the model fails, the model depth has to be increased to reflect the real behavior of the system in higher detail. Precision is the feedback of the errors and uncertainties of the model parameter determination on the simulation results. If the resulting deviation is below the reproducibility of the experimental data that is to be substituted by the model, the model precision is sufficient. If the model fails, the underlying parameter determination concept has to be improved. The difference between accuracy and prediction is depicted in Figure 3 .
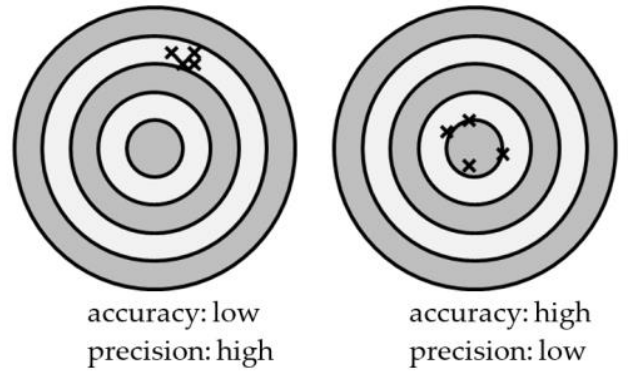

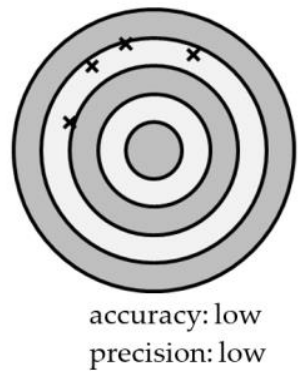

precision: low

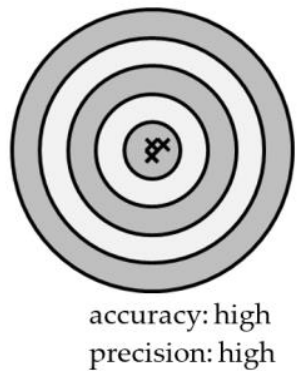

Figure 3. Visualization of accuracy and precision.

Validated and predictive process models for solid-liquid extractions exist for more than two decades. Kassing et al. [16,17] give an overview of different process modelling approaches. These studies, based on pepper and vanilla, predict influences of different particle diameters, solid/liquid ratios, and residence times. Both et al. [18-21] extended the validation on sugar and tea for different process concepts like maceration and percolation, recycling-mode percolation, as well as different residence times and solid/liquid ratios. They even showed the scale independent validity of the model by means of a scale up industrial level study for the extraction of sugar beet [18]. Further-on, salvia, fennel and yew [22,23] were added. Recently, Sixt et al. [24] added annual mugwort, assessing the influence of pressure, temperature, and solvent ratios on the extraction and enhanced the research on yew [25]. As a consequence, various studies exist, which prove that those models are valid to predict experimental data at various scales and different points of operation and feedstocks, thus they are accurate and therefore the model depth is sufficient. 
A detailed discussion and quantification of model precision has not yet been provided. Model precision rates the impacts of the errors of experimental model parameter determination on the simulation results. As a consequence, a model is precise, if the feedback of the experimental errors on the simulation is smaller compared to the data gained through field experiments. In that case, the proven accurate model has a sufficient precision to substitute experiments for process optimization, design and control. Kassing et al. [17] did extensive research on the equilibrium determination and the error propagation but did not show the feedback of the parameter determination on the simulation results. To close this gap, a generalized statistics-based comparison of the simulation error and the experimental error is shown to complete the engineering toolbox.

\section{Modelling of Solid-Liquid Extraction}

Data-driven process design is the key to efficient chemical engineering. Especially for important unit operations like continuous distillation, liquid-liquid extraction, and adsorption, graphical methods for process design as well as detailed models are available. Both models (stage construction for binary mixtures after McCabe-Thiele and ternary mixtures in Gibbs diagrams (mostly liquid-liquid extraction) [26]) are sketched in Figure 4. They rely on equilibrium stages that are reached in the system due to thermodynamics. The real behavior is then taken into account by the stage efficiency. There is an approach to adapt these methods to phytoextraction processes, but a comparable accuracy and wide spread use was not achieved [27]. This is mainly due to botanical and equipment constraints. On the botanical side, the plant tissue is highly compartmented and therefore different mass transport phenomena and limitations have to be taken into account. Moreover, there are target molecules that are not entirely adsorbed to the plant matrix, e.g., essential oils, that are often located in oil seams or trachoma cells in liquid state. Therefore, they can easily be washed out of the plant matrix, which is why an equilibrium stage model fails because no explicit phase equilibrium occurs. A look at the equipment side reveals a variety of different apparatus for phytoextraction [28]. Besides the often used batch equipment, like maceration and hydro-distillation, a number of continuously operated equipment is commercially available with their individual fluid dynamics that have to be taken into account for proper process design. Moreover, the fluid dynamic behavior of these devices is not steady but is subject to cyclic switch times like in carousel extractors.

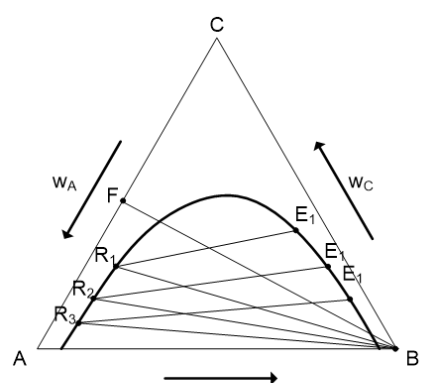

$w_{B}$

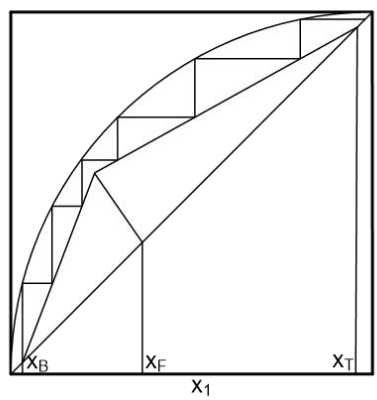

Botany:

- No strict equilibrium relationships

- Complex and diverse feedstock

- Compartments and wide range of mass transport phenomena

Equipment:

- Various, specialized types

- Complex and individual fluid dynamics

- Often batch

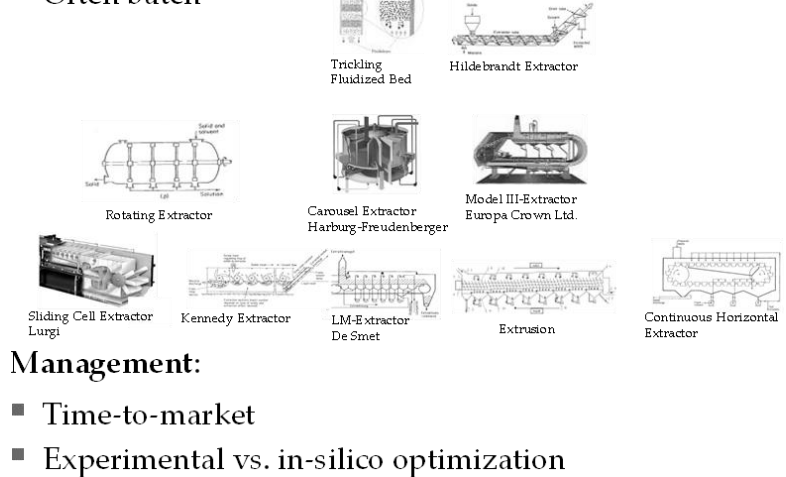

Figure 4. Need for rigorous modelling in phytoextraction, see [16] for more details on equipment. 
The model description of solid-liquid extraction has been researched for some time. The equation system can usually be divided into an apparatus-specific part, for example mass balances for flow tubes or stirred vessels, and a matrix-specific part which images the mass transport of individual components of the plant into the solvent. The goals of the modelling are either a reduction of attempts for process optimization or the deepening of the basic understanding. In addition to purely empirical models, which usually can only interpolate measured values, a number of predictive models for the matrix effects have been established [28].

- Shrinking Core: In the Shrinking Core model, a solvent front passes through a spherical particle. At the boundary layer between solvent and solid, the mass transfer of the target components take place. The model is based on gas-solid reactions in porous pellets [29].

- Broken and Intact Cells: The Broken and Intact Cells model is based on the idea that the target components are found both inside the plant particles, as well as in broken vacuoles or oil channels. This assumption is based on real extraction experiments in which extraction is carried out very rapidly at the beginning (near-surface components or broken vacuoles and oil channels). Subsequently, the extraction rate is greatly retarded (intact cells and oil channels). In the first case, there is no diffusion limitation, but in the second case there is a strong diffusion limitation of the extraction [30,31].

- Pore Diffusion model: The Pore Diffusion model originates from chromatography. The solvent diffuses into the porous particle and desorbs the components. Subsequently, the back diffusion and the subsequent removal take place in the core flow. Again, the basic idea of the Broken and Intact Cell model can be implemented by means of radial pore size and active substance distribution [17].

Table 1 gives an overview of various modelling approaches, material systems, solvents and apparatuses.

The extraction can be carried out as a leaching process (percolation) or as an equilibrium process (maceration). In the following, the percolation model is described in more detail.

The percolation process is represented by several sub-models. On the one hand, the distributed-plug-flow model (DPF) is used to represent the macroscopic mass transport within the percolation column, and on the other hand, the diffusion in the porous particle is modeled using a transport equation. In order to map the relationship between the residual load of the respective component in the particle and in the solvent, various equilibrium relationships are used.

The Shrinking Core and the Broken and Intact Cells model are not implemented because a pore diffusion approach gives the highest degree of detail compared to the other two theories. Also, the model is already established and widely used in chromatography.

All sub models are explained in more detail below. 
Table 1. Overview of modelling approaches, plug flow (PF), stirred tank reactor (STR), distributed plug flow (DPF), pulsed electrical field (PEF).

\begin{tabular}{|c|c|c|c|c|c|c|c|}
\hline Author and Year & Ref. & Fluid & Plant Material & Target Component & Equilibrium & Particle/Shape/Model & Flux \\
\hline Akgün 2000 & [32] & $\mathrm{scCO}_{2}$ & Lavender flower & Essential oil & Constant & Porous particle, Shrinking Core & PF \\
\hline Al-Jabari 2003 & [33] & $\mathrm{scCO}_{2}$ & - & - & Langmuir & - & STR \\
\hline Bulley 1984 & [34] & $\mathrm{scCO}_{2}$ & Rape & Fatty oil & - & - & $\mathrm{PF}$ \\
\hline Cacace 2003 & [35] & Ethanol, $\mathrm{SO}_{2}$ in Water & Berries & $\begin{array}{c}\text { Phenols, } \\
\text { Anthocyanins }\end{array}$ & Linear & - & STR \\
\hline Carrin 2008 & [36] & Hexane & Sunflower & Fatty Oil & Linear & Porous particle & DPF, cross-current \\
\hline Catchpole 1996 & [37] & Liquid $\mathrm{CO}_{2}$ & $\begin{array}{c}\text { Salvia, celery and } \\
\text { coriander seed }\end{array}$ & Essential and fatty oil & Linear & $\begin{array}{l}\text { Sphere, Cylinder, parabolic } \\
\text { concentration profile }\end{array}$ & $\mathrm{PF}$ \\
\hline Chalermachat 2003 & {$[38]$} & Water & Beetroot & Pigments & - & Porous cylinder & STR, PEF \\
\hline Chia 2015 & [39] & $\mathrm{scCO}_{2}$ (Soxhlet) & Rice bran oil & Tocopherol & - & $\begin{array}{l}\text { Logistic, Simple Single } \\
\text { Plate, Diffusion }\end{array}$ & - \\
\hline Cocero and Garcia 2001 & [40] & $\mathrm{scCO}_{2}$ & Sunflower & Fatty oil & Linear & No internal diffusion & DPF \\
\hline De Franca 2000 & [41] & SCF & Palm oil & Fatty oil, Carotenoids & Constant & - & $\mathrm{PF}$ \\
\hline Del Valle 2000 & [42] & $\mathrm{scCO}_{2}$ & Rape oil, basil & Essential and fatty oil & Linear & Sphere & $\mathrm{PF}$ \\
\hline Del Valle 2003 & [43] & $\mathrm{scCO}_{2}$ & Chili & Essential oil & Linear & Sphere & $\mathrm{PF}$ \\
\hline Del Valle 2005 & [44] & $\mathrm{scCO}_{2}$ & $\begin{array}{c}\text { Different Latin } \\
\text { American plants }\end{array}$ & Essential and fatty oil & Linear & Shrinking core & DPF \\
\hline Diankov 2008 & [46] & Water & Tabaco & - & - & Plates, Shrinking core & STR \\
\hline Egorov 2015 & [47] & $\mathrm{scCO}_{2}$ & Pumpkinseed & - & - & $\begin{array}{c}\text { Shrinking core, } \\
\text { particle size distribution }\end{array}$ & DPF \\
\hline Espinoza-Perez 2007 & [48] & Water & Coffee beans & Caffeine & Linear & Sphere & $\mathrm{PF}$ \\
\hline Esquivel 1999 & [49] & $\mathrm{scCO}_{2}$ & Olives bowl & Fatty oil & Linear & Porous particle & $\mathrm{PF}$ \\
\hline Ferreira 2002 & {$[50]$} & $\mathrm{scCO}_{2}$ & Black pepper & Essential oil & - & Broken and intact cells & $\mathrm{PF}$ \\
\hline Fiori 2007 & [51] & $\mathrm{scCO}_{2}$ & Vegetable seed & Fatty oil & Linear & Broken and intact cells & DPF \\
\hline Fiori 2008 & {$[52]$} & $\mathrm{scCO}_{2}$ & Grape kernels & Fatty oil & Linear & Broken and intact cells & DPF \\
\hline Fiori 2009 & [53] & $\mathrm{scCO}_{2}$ & Oilseed & Fatty oil & - & $\begin{array}{l}\text { Broken and intact cells und shrinking } \\
\text { core, particle size distribution }\end{array}$ & DPF \\
\hline
\end{tabular}


Table 1. Cont.

\begin{tabular}{|c|c|c|c|c|c|c|c|}
\hline Author and Year & Ref. & Fluid & Plant Material & Target Component & Equilibrium & Particle/Shape/Model & Flux \\
\hline Goodarznia and Eikani 1998 & [54] & $\mathrm{scCO}_{2}$ & $\begin{array}{c}\text { Rosemary, basil, } \\
\text { caraway, marjoram }\end{array}$ & Essential oil & Linear & Sphere & DPF \\
\hline Goto 1990 & [55] & $\mathrm{scCO}_{2}$ & Wood & Lignin & Linear & $\begin{array}{c}\text { Porous particle, } \\
\text { parabolic concentration profile }\end{array}$ & $\mathrm{PF}$ \\
\hline Goto 1993 & {$[56]$} & $\mathrm{scCO}_{2}$ & Peppermint & Essential oil & Linear & Porous particle & $\mathrm{PF}$ \\
\hline Goto 1996 & [57] & $\mathrm{scCO}_{2}$ & Rape oil & Fatty oil & Constant & Shrinking core & DPF \\
\hline Guerrero 2008 & {$[58]$} & Ethanol/Water & Grape pomace & Polyphenols & - & Sphere & $\mathrm{PF}$ \\
\hline Ji 2006 & [59] & Water & Gardenia fruit & Geniposide & Langmuir & Shrinking core & STR, ultrasound \\
\hline Kim and Hong 2001 & [61] & $\mathrm{scCO}_{2}$ & Spearmint & Essential oil & Constant & - & $\mathrm{PF}$ \\
\hline Kim and Hong 2002 & [62] & $\mathrm{scCO}_{2}$ & Spearmint & Essential oil & Constant & Shrinking core & $\mathrm{PF}$ \\
\hline Lee 1986 & [63] & $\mathrm{scCO}_{2}$ & Rape oil & Fatty oil & Constant & No internal diffusion & $\mathrm{PF}$ \\
\hline Lópex-Padilla 2017 & [64] & $\mathrm{scCO}_{2}$ & Marigold & Fatty oil & BIC-type & Broken and intact cells & PF \\
\hline Lucas 2007 & [65] & $\mathrm{scCO}_{2}$ & Wheat sprouts & Fatty oil & Linear & - & $\mathrm{PF}$ \\
\hline Machmudah 2006 & {$[66]$} & $\mathrm{scCO}_{2}$ & Nutmeg & Fatty oil & BIC-type & Broken and intact cells Shrinking core & $\mathrm{PF}$ \\
\hline Macias-Sanchez 2009 & [67] & $\mathrm{scCO}_{2}+5 \%$ Ethanol & Micro algae & Carotenoids & Linear & Sphere & $\mathrm{PF}$ \\
\hline Madras 1994 & {$[68]$} & $\mathrm{scCO}_{2}$ & Soil & Organic pollutants & Freundlich & Shrinking core & DPF \\
\hline Marrone 1998 & [70] & $\mathrm{scCO}_{2}$ & Almond oil & Fatty oil & BIC-type & Broken and intact cells & $\mathrm{PF}$ \\
\hline Martinez 2003 & [71] & $\mathrm{scCO}_{2}$ & Ginger & Oleoresin & - & Logistic & $\mathrm{PF}$ \\
\hline Nagy 2008 & [72] & $\mathrm{scCO}_{2}$ & Chili & Essential oil & - & Particle size distribution & $\mathrm{PF}$ \\
\hline Özkal 2005 & [73] & $\mathrm{scCO}_{2}$ & Apricot kernels & Apricot kernel oil & BIC-type & Broken and intact cells & $\mathrm{PF}$ \\
\hline Peker 1992 & [74] & $\mathrm{scCO}_{2}$ & Coffee beans & Caffeine & Linear & Sphere & PF \\
\hline Perrut 1997 & [75] & $\mathrm{scCO}_{2}$ & Sunflower seed & Fatty oil & BIC-type & Porous particle & $\mathrm{PF}$ \\
\hline Pinelo 2006 & [76] & Ethanol & Grape by-products & Antioxidants & - & Sphere & STR \\
\hline Poletto and Reverchon 1996 & [77] & $\mathrm{scCO}_{2}$ & Vegetable & Essential and fatty oil & Linear & - & $\mathrm{PF}$ \\
\hline Reis-Vasco 2000 & [78] & $\mathrm{scCO}_{2}$ & Pennyroyal & Essential oil & Linear & Broken and intact cells & DPF \\
\hline Reverchon 1996 & [79] & $\mathrm{scCO}_{2}$ & Salvia oil & Essential oil & Linear & Sphere, cylinder, rod & $\mathrm{PF}$ \\
\hline Reverchon and Marrone 1997 & [80] & $\mathrm{scCO}_{2}$ & Cloves & Essential oil & Linear & No internal diffusion & DPF \\
\hline Reverchon 1999 & [81] & $\mathrm{scCO}_{2}$ & Fennel & Essential and fatty oil & BIC-type & Broken and intact cells & PF \\
\hline
\end{tabular}


Table 1. Cont

\begin{tabular}{|c|c|c|c|c|c|c|c|}
\hline Author and Year & Ref. & Fluid & Plant Material & Target Component & Equilibrium & Particle/Shape/Model & Flux \\
\hline Reverchon 2000 & [82] & $\mathrm{scCO}_{2}$ & Rosehip oil & Fatty oil & BIC-type & Broken and intact cells & $\mathrm{PF}$ \\
\hline Reverchon and Marrone 2001 & [83] & $\mathrm{scCO}_{2}$ & Vegetable oil & Fatty oil & BIC-type & Broken and intact cells & $\mathrm{PF}$ \\
\hline Rosa 2016 & [84] & $\mathrm{scCO}_{2}$ & Green coffee beans & Cafestole, Kahweole & Linear & No internal diffusion & DPF \\
\hline Roy 1996 & [85] & $\mathrm{scCO}_{2}$ & Ginger oil & Essential oil & Constant & Shrinking core & DPF \\
\hline Salamatin 2017 & [86] & $\mathrm{scCO}_{2}$ & Pumpkin seed & - & - & $\begin{array}{l}\text { Shrinking core und Broken } \\
\text { and intact cells }\end{array}$ & - \\
\hline Seikova 2003 & [87] & Water & Belladonna & Alkaloids & - & Sphere, cylinder, rod & STR \\
\hline Seikova 2004 & [88] & Water $\mathrm{pH} 9(\mathrm{NaOH})$ & Tomato seed & Proteins & - & Sphere, cylinder, rod & STR \\
\hline Simeonov 1999 & [89] & Water & Tabaco leaves, oak bark & - & Linear & Sphere, cylinder, rod & STR \\
\hline Simeonov 2003 & [90] & Methanol, Petrol ether & Indigo, coriander & $\begin{array}{l}\text { Essential oil, Fatty oil, } \\
\text { Isoflavonoids }\end{array}$ & - & Sphere, cylinder, rod & STR \\
\hline Simeonov 2008 & [91] & $70 / 30 v / v$ Ethanol/Water & Root of bloody geranium & - & - & Sphere, cylinder, rod & STR \\
\hline Skerget 2001 & [92] & $\mathrm{scCO}_{2}$ & $\begin{array}{l}\text { Milk thistle, pepper, } \\
\text { chili, cacao }\end{array}$ & - & Linear & $\begin{array}{c}\text { Porous particle, } \\
\text { parabolic concentration profile }\end{array}$ & STR \\
\hline Sovova 1994 & {$[30]$} & $\mathrm{scCO}_{2}$ & Vegetable & Fatty oil & Constant & Broken and intact cells & $\mathrm{PF}$ \\
\hline Sovova 1994 & [93] & $\mathrm{scCO}_{2}$ & Caraway & Essential oil & Linear & Broken and intact cells & PF \\
\hline Sovova 2005 & [31] & $\mathrm{scCO}_{2}$ & - & - & BIC-type & Broken and intact cells & $\mathrm{PF}$ \\
\hline Stamenic 2008 & [94] & $\mathrm{scCO}_{2}$ & $\begin{array}{l}\text { Thyme, celery, } \\
\text { valerian root }\end{array}$ & Essential oil & - & $\begin{array}{l}\text { Broken and intact cells, } \\
\text { trichoma cells }\end{array}$ & DPF \\
\hline Stastova 1996 & [95] & $\mathrm{scCO}_{2}$ & Sea buckthorn & Fatty oil & Constant & Broken and intact cells & $\mathrm{PF}$ \\
\hline Strube 2008 & [96] & $20 \%(w / w)$ Water/Ethanol & Brazilian amargo & Terpenoids & Langmuir & $\begin{array}{c}\text { Porous particle, } \\
\text { parabolic concentration profile }\end{array}$ & DPF \\
\hline Strube 2012 & {$[17]$} & Ethanol, Ethyl acetate & Pepper, vanilla & Piperine, Vanillin & Langmuir & Porous particle & DPF \\
\hline Strube 2017 & [25] & Water (PHWE) & Yew & 10-deacetylbaccatin III & Constant & Porous particle & $\begin{array}{c}\text { DPF with } \\
\text { degradation kinetics }\end{array}$ \\
\hline Teixera de Souza 2008 & [97] & $\mathrm{scCO}_{2}$ & Candeia tree & Essential oil & - & - & $\mathrm{PF}$ \\
\hline Veloso 2008 & [98] & Hexane, Water, Alcohols & Oil seed & Fatty oil & Linear & $\begin{array}{c}\text { Porous particle, } \\
\text { no internal diffusion }\end{array}$ & DPF, cross-current \\
\hline Winitsorn 2008 & [99] & Ethanol & Tamarind, green tea & - & - & Porous particle & STR \\
\hline Wu and Hou 2001 & [100] & $\mathrm{scCO}_{2}$ & Egg yolk & Fatty oil & BIC-type & No internal diffusion & $\mathrm{PF}$ \\
\hline Zizovic 2005 & [101] & $\mathrm{scCO}_{2}$ & $\begin{array}{l}\text { Basil, rosemary, } \\
\text { marjoram, pennyroyal }\end{array}$ & Essential oil & - & Trichoma cells & DPF \\
\hline Zizovic 2007 & [102] & $\mathrm{scCO}_{2}$ & Marigold, chamomile & Essential oil & - & $\begin{array}{l}\text { Sphere with channels, } \\
\text { no internal diffusion }\end{array}$ & DPF \\
\hline
\end{tabular}




\subsection{Distributed-Plug-Flow (DPF) Model}

The DPF model describes macroscopic mass transport in the liquid phase for each component and is given in Equation (1).

$$
\frac{\partial c_{L}(z, t)}{\partial t}=D_{a x} \cdot \frac{\partial^{2} c_{L}(z, t)}{\partial z^{2}}-\frac{u_{z}}{\varepsilon} \cdot \frac{\partial c_{L}(z, t)}{\partial z}-\frac{1-\varepsilon}{\varepsilon} \cdot k_{f} \cdot a_{P} \cdot\left[c_{L}(z, t)-c_{P}(r=R, z, t)\right]
$$

The model equation consists of several terms. The first term describes the accumulation, i.e., the time-related enrichment of the target and minor components in the solvent. The second term represents the so-called axial dispersion. $\mathrm{D}_{\mathrm{ax}}$ is the axial dispersion coefficient that has to be adapted to the real flow conditions. If this term is neglected, only the flow profile of the ideal flow tube (PFR) is displayed. However, if $\mathrm{D}_{\mathrm{ax}}$ is greater than zero, an expansion of the residence time distribution up to the behavior of the ideal stirred tank can be modeled. In the present case, the axial dispersion is determined by a correlation over the Reynolds and Péclet numbers [17]. First, the Reynolds number Re must be calculated. This sets the inertial forces in relation to the viscous forces in fluids. Here, $\mathrm{u}_{\mathrm{z}}$ is the empty tube velocity of the fluid, $d_{P \text {,mean }}$ is the mean particle diameter, $\rho_{\mathrm{L}}$ is the density of the fluid, $\eta$ is the dynamic viscosity of the fluid and $\varepsilon$ is the void fraction of the medium through which it flows.

$$
\operatorname{Re}=\frac{\mathrm{u}_{\mathrm{z}} \cdot \mathrm{d}_{\mathrm{P}, \text { mean }} \cdot \rho_{\mathrm{L}}}{\eta \cdot \varepsilon}
$$

Based on the Reynolds number, the Péclet number can be determined. It forms the relationship between convective and dispersive mass transfer. The correlation proposed by Chung applies only to Reynolds numbers between $10^{-3}$ and $10^{3}$ [103].

$$
\mathrm{Pe}=\frac{0.2}{\varepsilon}+\frac{0.011}{\varepsilon}(\varepsilon \cdot \operatorname{Re})^{0.48} \quad 10^{-3}<\operatorname{Re}<10^{3}
$$

From the Péclet number in turn follows the axial dispersion coefficient $\mathrm{D}_{\mathrm{ax}}$ according to the Equation (4). In addition, the value of $\mathrm{D}_{\mathrm{ax}}$ can be determined by tracer experiments, which are common practice in chromatography [104-106].

$$
\mathrm{D}_{\mathrm{ax}}=\frac{\mathrm{d}_{\mathrm{P}, \mathrm{mean}} \cdot \mathrm{u}_{\mathrm{z}}}{\varepsilon \cdot \mathrm{Pe}}
$$

The third term in Equation (1) describes the convection that results from the pumping of the solvent. The empty tube velocity is represented by $u_{z}$ and the void level of the fixed bed by $\varepsilon$. The differential $\partial c_{L}(z, t) / \partial z$ is the local concentration profile of the respective component in the axial direction.

The last term describes the mass transfer from the particle into the fluid of each component. The mass transfer coefficient $\mathrm{k}_{\mathrm{f}}$ and the specific surface area of the particles ap represent the model parameters. If spherical particles are assumed, the following relationship arises between the specific surface area and the particle radius:

$$
\mathrm{a}_{\mathrm{P}}=\frac{6}{\mathrm{~d}_{\mathrm{P}, \text { mean }}}
$$

The mass transport coefficient $\mathrm{k}_{\mathrm{f}}$ is also determined by a correlation of the Schmidt (6), the Sherwood (7), and the Reynolds number (2) for the particles [16].

$$
\begin{gathered}
\mathrm{Sc}=\frac{\eta}{\rho_{\mathrm{L}} \cdot \mathrm{D}_{12}} \\
\mathrm{Sh}=\frac{\mathrm{k}_{\mathrm{f}} \cdot \mathrm{d}_{\mathrm{P} \text {,mean }}}{\mathrm{D}_{12}}
\end{gathered}
$$


$D_{12}$ is the binary diffusion coefficient between the respective component and the solvent. This model parameter must be determined from an actual extraction. By means of the correlation below, the mass transfer coefficient $\mathrm{k}_{\mathrm{f}}$ is then calculated [16].

$$
\mathrm{Sh}=2+1.1 \cdot \mathrm{Sc}^{0.33} \cdot \mathrm{Re}^{0.6}
$$

The DPF model is a partial differential equation of the second order. The solution therefore requires two boundary conditions and an initial condition. At the beginning of the process, the solvent is unloaded, so the concentration of extracted components is zero.

$$
\begin{array}{ll}
\mathrm{c}_{\mathrm{L}}(\mathrm{z}, \mathrm{t})=0 & \mathrm{t}=0 \\
& 0 \leq \mathrm{z} \leq \mathrm{L}
\end{array}
$$

The boundary condition for the axial dispersion represents a material balance around the inlet zone of the flow tube [107]. The fluid is first conveyed by convection to percolation. If the fluid enters, it is transported away inside the tube by convection and diffusion, which is represented by Equation (10).

$$
\mathrm{u}_{\mathrm{z}} \cdot \mathrm{c}_{\mathrm{L}}(\mathrm{z}, \mathrm{t})=\left.\mathrm{D}_{\mathrm{ax}} \cdot \frac{\partial \mathrm{c}_{\mathrm{L}}(\mathrm{z}, \mathrm{t})}{\partial \mathrm{z}}\right|_{\mathrm{z}=0} \quad \begin{aligned}
& \mathrm{t}>0 \\
& \mathrm{z}=0
\end{aligned}
$$

At the outlet of the flow tube, the axial concentration change is negligible. The derivative of the concentration in axial direction is therefore zero.

$$
\left.\frac{\partial c_{\mathrm{L}}(\mathrm{z}, \mathrm{t})}{\partial \mathrm{z}}\right|_{\mathrm{z}=\mathrm{L}}=0 \quad \begin{aligned}
& \mathrm{t}>0 \\
& \mathrm{z}=\mathrm{L}
\end{aligned}
$$

\subsection{Pore Diffusion (PD) Model}

The mass transport of the components from the pores of the plant material into the fluid is represented by a pore diffusion model. The model assumes that the solvent enters the particle by diffusion, where it dissolves the respective component and diffuses back into the liquid core, as shown in Figure 5.

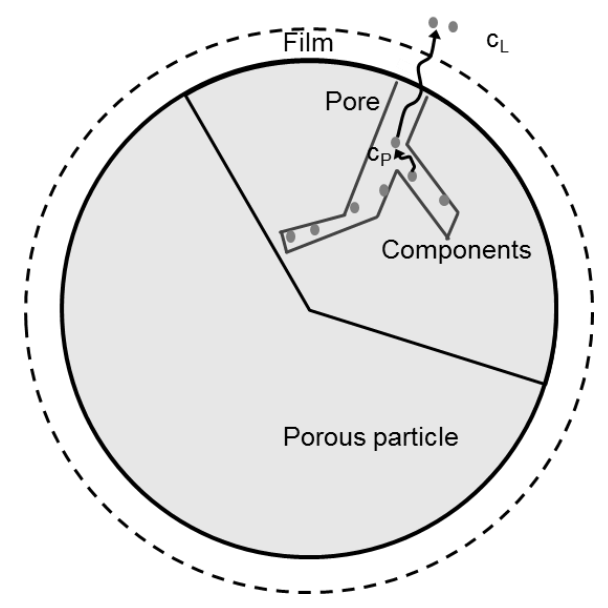

Figure 5. Principle of the pore diffusion model.

In the case of spherical particles, Equation (12) results for the pore diffusion model from Fick's second law.

$$
\frac{\partial q(z, r, t)}{\partial t}=D_{\text {eff }}(r) \cdot\left(\frac{\partial^{2} c_{P}(z, r)}{\partial r^{2}}+\frac{2}{r} \cdot \frac{\partial c_{P}(z, r)}{\partial r}\right)+\frac{\partial D_{\text {eff }}(r)}{\partial r} \cdot \frac{\partial c_{P}(z, r)}{\partial r}
$$


In the equation, $\partial \mathrm{q}(\mathrm{z}, \mathrm{r}, \mathrm{t}) / \partial \mathrm{t}$ represents the time-dependent loading of the solid with the respective component. These will be discussed in more detail in the following chapter. The concentration of the target component is expressed by $c_{P}$, which is radially resolved. $D_{\text {eff }}$ represents the effective diffusion coefficient, which is calculated starting from the binary diffusion coefficient $\mathrm{D}_{12}$, by means of the porosity of the plant material $\varepsilon_{\mathrm{P}}$, the tortuosity $\tau$ and the constrictivity factor $\delta$ [17].

$$
\mathrm{D}_{\text {eff }}=\frac{\mathrm{D}_{12} \cdot \varepsilon_{\mathrm{P}} \cdot \delta}{\tau}
$$

For the parameters $\varepsilon_{\mathrm{P}}, \tau$, and $\delta$, corresponding correlations exist [17]. In addition, they can be determined by suitable methods, such as the mercury penetration method. In this work, they are summarized to a sum parameter and determined by an extraction experiment.

Since the pore diffusion model is also a partial differential equation of the second order, two boundary conditions and an initial condition are needed. At the beginning of the extraction, the extraction material is maximally loaded at each location in the axial and in the radial direction, which is taken into account by Equation (14).

$$
\mathrm{q}(\mathrm{z}, \mathrm{r}, \mathrm{t})=\mathrm{q}_{\mathrm{m}}(\mathrm{r}) \quad \begin{aligned}
& \mathrm{t}=0 \\
& 0<\mathrm{z} \leq \mathrm{L} \\
& \\
& 0<\mathrm{r} \leq \mathrm{R}
\end{aligned}
$$

During the extraction, a concentration profile is formed in the particle. Based on the assumption that the solvent penetrates evenly into the spherical particle from all sides and does not diffuse beyond the center of the particle, the local derivative of the radial concentration profile must be zero in the particle center.

$$
\begin{array}{cl}
\frac{\partial \mathrm{c}_{\mathrm{P}}(\mathrm{z}, \mathrm{r}, \mathrm{t})}{\partial \mathrm{r}}=0 & \mathrm{t}>0 \\
& 0<\mathrm{z} \leq \mathrm{L} \\
& \mathrm{r}=0
\end{array}
$$

At the outer particle edge, a mass balance serves as a boundary condition. The extracted component first passes by diffusion to the particle edge and from there into the fluid. The mass transfer coefficient $\mathrm{k}_{\mathrm{f}}$ links the pore diffusion model with the DPF model.

$$
D_{\text {eff }}(r) \cdot \frac{\partial c_{P}(z, r, t)}{\partial r}=k_{f} \cdot\left[c_{L}(z, t)-c_{P}(r, z, t)\right] \quad r=R
$$

\subsection{Equilibrium}

For the design and modelling of phytoextraction, the plant particles are considered to be porous spheres in which the components are adsorbed. The solvent must diffuse into the pores, there dissolve the components and move back into the core of the fluid. Within the pores is an adsorption/desorption equilibrium that can be described by equilibrium lines. The approaches available in the literature are described in more detail below [28,108]. The loading q represents the linking of the equilibrium lines to the pore diffusion model.

\subsubsection{Henry}

The simplest form of equilibrium is Henry's linear approach. $\mathrm{K}_{\mathrm{H}}$ is the Henry coefficient, which is accessible experimentally and represents the proportionality factor between the concentration $\mathrm{c}$ and the loading $\mathrm{q}$.

$$
\mathrm{q}=\mathrm{K}_{\mathrm{H}} \cdot \mathrm{c}
$$




\subsubsection{Freundlich}

The equilibrium relationship according to Freundlich represents an exponential approach. The Henry's approach is extended by the exponent $\mathrm{n}$, which can also be determined experimentally.

$$
\mathrm{q}=\mathrm{K}_{\mathrm{F}} \cdot \mathrm{c}^{\mathrm{n}}
$$

\subsubsection{Langmuir}

The Langmuir equilibrium relationship results from first order adsorption and desorption kinetics. The coefficient $\mathrm{K}_{\mathrm{L}}$ is the quotient of the rate constants of adsorption and desorption. It is also determinable by equilibrium experiments. In contrast to the two above-mentioned equilibrium approaches, the Langmuir shape converges to a limit value, i.e., to a maximum loading of the solid $\mathrm{q}_{\max }$.

$$
\mathrm{q}=\mathrm{q}_{\max } \cdot \frac{\mathrm{K}_{\mathrm{L}} \cdot \mathrm{c}}{1+\mathrm{K}_{\mathrm{L}} \cdot \mathrm{c}}
$$

\subsubsection{Modified-Langmuir}

Especially in phytoextraction, there are no pure adsorption or desorption equilibria. A high proportion of the valuable substance in dissolved e.g., in the vacuole or in cell spaces. This corresponds to the model concept "Broken and Intact Cells" by Sovová [30]. Kassing et al. [16,17] have adopted this concept in the pore diffusion model and implemented it using a radial target component distribution. If the target component distribution measurable by methods such as Raman mapping [109], this can be implemented. If no corresponding data is available, the introduction of the capacity factor a as a macroscopic parameter reflects the basic idea of the Broken and Intact Cells model, which is based on non-steady-differentiable equilibrium lines [31,75]. If the solvent is able to dissolve and transport away a large amount of the target substances, or if it is accessible, only a small fraction, which is actually adsorbed in the cell or between the cells, remains. The capacity factor a leads then to a modified version of the Langmuir equilibrium.

$$
\mathrm{q}=\mathrm{q}_{\max } \cdot \mathrm{a} \cdot \frac{\mathrm{K}_{\mathrm{L}} \cdot \mathrm{c}}{1+\mathrm{K}_{\mathrm{L}} \cdot \mathrm{c}}
$$

\section{Model Parameter Determination}

Figure 6 explains the procedure of stepwise determination of model parameters with separated independent effects. Altenhöner [104] proposed this procedure of equation assembly at first for chromatography process modelling, which was transferred successfully to solid liquid extractions [17].

At first, the laboratory scale equipment is characterized once by tracer experiments, allowing a direct transfer to other scales, if their fluid dynamics is characterized as well [18]. This fills the first boxed term of the DPF-model equation; all other terms are not needed and neglected. Therefore, no interference of model parameter occurs, and the effects and their characteristic parameters are discriminated distinctively. Afterward, thermodynamic equilibrium phase behavior is implemented by i.e., a Langmuir-type equation, where $\mathrm{K}$ is representative for the slope of the equilibrium curve at infinite dilution and $\mathrm{q}_{\max }$ is the overall amount of the regarded component within the plant material by nature. Finally, the mass transfer coefficients are determined for the DPF model by i.e., correlations, using the Péclet and Reynolds number, as shown before. The effective diffusion coefficient needed for the pore diffusion model is measured by means of an extraction experiment. Therefore, such an equation setup is assembled stepwise. As the index $i$ in Figure 6 indicates, this procedure is only limited by the number of distinguishable und quantifiable components. In most cases, the parameter determination is carried out in a standardized apparatus [16,17] consuming about $150 \mathrm{~g}$ of plant material and a few liters of solvent. 


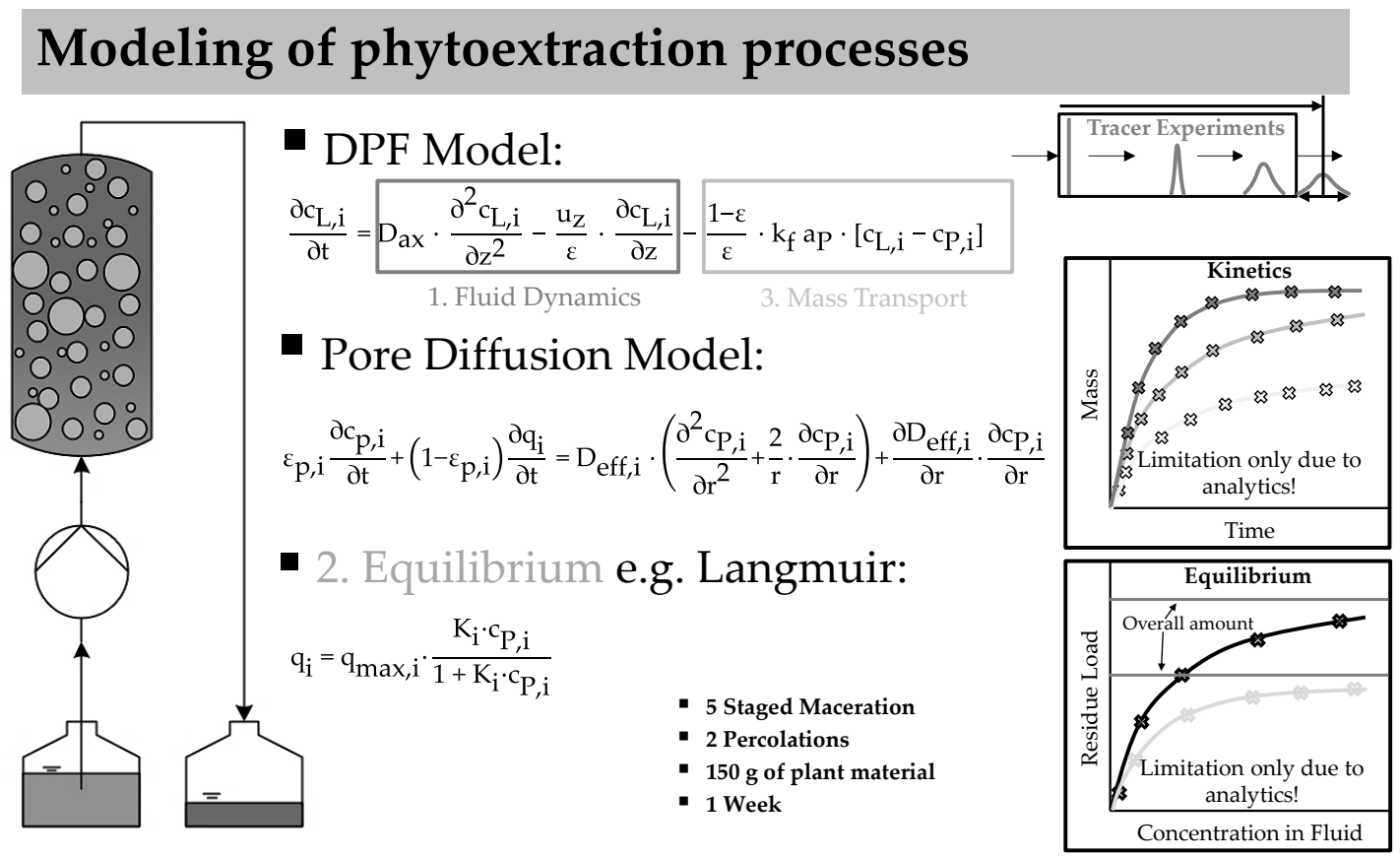

Figure 6. Stepwise equation assembly in phytoextraction (solid liquid extraction).

\subsection{Overall Amount}

The overall amount of each considered component is determined by means of an exhaustive percolation and Equation (21). Where $\mathrm{q}_{\max }$ is the loading of the plant material with the respective component, $\mathrm{c}_{\mathrm{C} o m p}$ the concentration in the extract, $\mathrm{V}_{\text {Extract }}$ the extract volume and $\mathrm{m}_{\text {Plant }}$ the amount of plant material used. RM is the residual moisture of the plant material and $\rho_{\text {Extract }}$ the extract's density.

$$
\mathrm{q}_{\max }=\frac{{ }^{\mathrm{c}_{\text {Comp }}} \cdot \mathrm{m}_{\text {Extract }}}{\mathrm{m}_{\text {Plant }} \cdot(1-\mathrm{RM}) \cdot \rho_{\text {Extract }}}
$$

The extraction yield is referred to the overall amount. The error propagation is given in Equation (22).

$$
\begin{aligned}
\Delta \mathrm{q}_{\max }=\left|\frac{\mathrm{m}_{\text {Extract }}}{\mathrm{m}_{\text {Plant }} \cdot(1-\mathrm{RM}) \cdot \rho_{\text {Extract }}}\right| \cdot \Delta \mathrm{c}_{\text {Comp }}+\left|\frac{\mathrm{c}_{\text {Comp }}}{\mathrm{m}_{\text {Plant }} \cdot(1-\mathrm{RM}) \cdot \rho_{\text {Extract }}}\right| \\
\cdot \Delta \mathrm{m}_{\text {Extract }}+\left|\frac{\mathrm{c}_{\text {Comp }} \cdot \mathrm{m}_{\text {Extract }}}{\left(\mathrm{m}_{\text {Plant }} \cdot(1-\mathrm{RM}) \cdot \rho_{\text {Extract }}\right)^{2}}\right| \cdot\left(\mathrm{m}_{\text {Plant }} \cdot(1-\mathrm{RM})\right) \\
\cdot \Delta \rho_{\text {Extract }}+\left|\frac{\mathrm{c}_{\text {Comp }} \cdot \mathrm{m}_{\text {Extract }}}{\left(\mathrm{m}_{\text {Plant }} \cdot(1-\mathrm{RM}) \cdot \rho_{\text {Extract }}\right)^{2}}\right| \cdot\left(\rho_{\text {Extract }} \cdot(1-\mathrm{RM})\right) \\
\cdot \Delta \mathrm{m}_{\text {Plant }}+\left|\frac{\mathrm{c}_{\text {Comp }} \cdot \mathrm{m}_{\text {Extract }}}{\left(\mathrm{m}_{\text {Plant }} \cdot(1-\mathrm{RM}) \cdot \rho_{\text {Extract }}\right)^{2}}\right| \cdot \mathrm{m}_{\text {Plant }} \cdot \rho_{\text {Extract }} \cdot \Delta \mathrm{RM}
\end{aligned}
$$

The error calculation for a representative example is depicted below. The data is:

- $\quad$ mass of plant material $20 \mathrm{~g}$;

- mass of solvent $5000 \mathrm{~g}$;

- density of solvent $791 \mathrm{~g} / \mathrm{L}$;

- concentration $0.03 \mathrm{~g} / \mathrm{L}$;

- $\quad$ and the residual moisture is $8 \%$.

The resulting overall amount is $1.03 \% \pm 0.0257 \%$ referred to dry mass. The relative deviation therefore is $\pm 2.57 \%$. The resulting individual errors in each step are given in Table 2 . 
Table 2. Error propagation for the overall amount measurement.

\begin{tabular}{cccc}
\hline Parameter & Deviation & Origin & Error \\
\hline$\Delta \mathrm{c}_{\text {Comp }}$ & $\pm 2 \%= \pm 0.0006 \mathrm{~g} / \mathrm{L} @ 0.03 \mathrm{~g} / \mathrm{L}$ & HPLC-analytics & $\pm 0.0206 \%$ \\
$\Delta \mathrm{m}_{\text {Plant }}$ & $\pm 0.01 \mathrm{~g}= \pm 0.05 \% @ 20 \mathrm{~g}$ & Last digit of balance & $\pm 0.0005 \%$ \\
$\Delta \mathrm{m}_{\text {Extract }}$ & $\pm 0.01 \mathrm{~g}= \pm 0.0002 \% @ 5000 \mathrm{~g}$ & Last digit of balance & $\pm 0.000002 \%$ \\
$\Delta \rho_{\text {Extract }}$ & $\pm 0.1 \mathrm{~g} / \mathrm{L}=0.012 \% @ 791 \mathrm{~g} / \mathrm{L}$ & Last digit of digital density meter & $\pm 0.00013 \%$ \\
$\Delta \mathrm{RM}$ & $\pm 0.5 \%$ & Reproducibility & $\pm 0.0045 \%$ \\
\hline \multicolumn{2}{c}{ Overall } & & $\pm 0.0257 \%$ \\
\hline
\end{tabular}

\subsection{Equilibrium}

The equilibrium between the respectively considered component in the solvent and in the solid is determined by means of multi-stage maceration. For this purpose, a defined amount of plant material and solvent is extracted for $24 \mathrm{~h}$ in a maceration vessel. This is followed by the removal of a sample before additional solvent is added and then a new equilibrium point is established. This process can be repeated as often and with any ratio of plant to solvent, as long as the mixture is still stirrable. The residual charge results per step as the ratio of the respective component in the extract to the total amount in the plant by means of Equation (23).

$$
\mathrm{q}_{\text {Comp }}=\frac{\mathrm{c}_{\text {Comp }} \cdot \mathrm{m}_{\text {Extract }}}{\mathrm{q}_{\max } \cdot \mathrm{m}_{\text {Plant }} \cdot(1-\mathrm{RM}) \cdot \rho_{\text {Extract }}}
$$

The error propagation is given in Equation (24).

$$
\begin{aligned}
& \Delta \mathrm{q}_{\text {Comp }}=\left|\frac{\mathrm{m}_{\text {Extract }}}{\mathrm{q}_{\max } \cdot \mathrm{m}_{\text {Plant }} \cdot(1-\mathrm{RM}) \cdot \rho_{\text {Extract }}}\right| \cdot \Delta \mathrm{c}_{\text {Comp }} \\
& +\left|\frac{{ }^{C} \text { Comp. }}{\mathrm{q}_{\text {max }} \cdot \mathrm{m}_{\text {Plant }} \cdot(1-\mathrm{RM}) \cdot \rho_{\text {Extract }}}\right| \cdot \Delta \mathrm{m}_{\text {Extract }} \\
& +\left|\frac{{ }^{c_{C o m p}} \cdot \mathrm{m}_{\text {Extract }}}{\left(\mathrm{q}_{\max } \cdot \mathrm{m}_{\text {Plant }} \cdot(1-\mathrm{RM}) \cdot \rho_{\text {Extract }}\right)^{2}}\right| \cdot\left(\mathrm{q}_{\max } \cdot \mathrm{m}_{\text {Plant }} \cdot(1-\mathrm{RM})\right) \\
& \cdot \Delta \rho_{\text {Extract }}+\left|\frac{\mathrm{c}_{\text {Comp }} \cdot \mathrm{m}_{\text {Extract }}}{\left(\mathrm{q}_{\max } \cdot \mathrm{m}_{\text {Plant }} \cdot(1-\mathrm{RM}) \cdot \rho_{\text {Extract }}\right)^{2}}\right| \\
& \cdot\left(\mathrm{q}_{\max } \cdot(1-\mathrm{RM}) \cdot \rho_{\text {Extract }}\right) \cdot \Delta \mathrm{m}_{\text {Plant }} \\
& +\left|\frac{{ }_{\text {Comp }} \cdot m_{\text {Extract }}}{\left(\mathrm{q}_{\text {max }} \cdot \mathrm{m}_{\text {Plant }} \cdot(1-\mathrm{RM}) \cdot \rho_{\text {Extract }}\right)^{2}}\right| \cdot \mathrm{q}_{\text {max }} \cdot \mathrm{m}_{\text {Plant }} \cdot \rho_{\text {Extract }}
\end{aligned}
$$

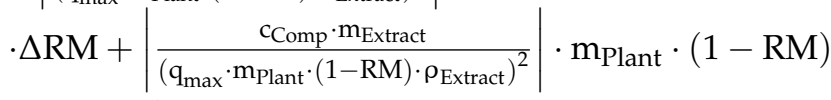

$$
\begin{aligned}
& \cdot \rho_{\text {Extract }} \cdot \Delta q_{\max }
\end{aligned}
$$

The error calculation for a representative example is depicted below. The data is

- mass of plant material $20 \mathrm{~g}$;

- mass of solvent $300 \mathrm{~g}$;

- density of solvent $791 \mathrm{~g} / \mathrm{L}$;

- overall amount $1 \%$;

- concentration $0.3 \mathrm{~g} / \mathrm{L}$;

- $\quad$ and the residual moisture is $8 \%$.

The residual load is $0.618 \% \pm 0.0314 \%$. The relative deviation therefore is $\pm 5.08 \%$. The details can be seen in Table 3. 
Table 3. Error propagation for the equilibrium measurement.

\begin{tabular}{|c|c|c|c|}
\hline Parameter & Deviation & Origin & Error \\
\hline$\Delta c_{\text {Comp. }}$ & $\pm 2 \%= \pm 0.006 \mathrm{~g} / \mathrm{L} @ 0.3 \mathrm{~g} / \mathrm{L}$ & HPLC-analytics & $\pm 0.0124 \%$ \\
\hline$\Delta \mathrm{m}_{\text {Plant }}$ & $\pm 0.01 \mathrm{~g}= \pm 0.05 \% @ 20 \mathrm{~g}$ & Last digit of balance & $\pm 0.0003 \%$ \\
\hline$\Delta \mathrm{m}_{\text {Extract }}$ & $\pm 0.01 \mathrm{~g}= \pm 0.0002 \% @ 300 \mathrm{~g}$ & Last digit of balance & $\pm 0.00002 \%$ \\
\hline$\Delta \rho_{\text {Extract }}$ & $\pm 0.1 \mathrm{~g} / \mathrm{L}=0.012 \% @ 791 \mathrm{~g} / \mathrm{L}$ & Last digit of digital density meter & $\pm 0.00008 \%$ \\
\hline$\Delta \mathrm{RM}$ & $\pm 0.5 \%$ & Reproducibility & $\pm 0.0027 \%$ \\
\hline$\Delta \mathrm{q}_{\max }$ & $\pm 2.5 \%$ & Error Propagation & $\pm 0.0159 \%$ \\
\hline \multicolumn{3}{|c|}{ Overall } & $0.618 \% \pm 0.0314 \%$ \\
\hline
\end{tabular}

\section{Model Validation}

The aim of this study is to provide a method for the analysis of the model precision in order to complete the toolbox towards proved model validation. Accuracy was shown through numerous successful applications of the model with different feedstocks and scales as listed above.

\subsection{Sensitivity Analysis}

The depicted experimental errors in the model parameter determination doubtlessly have a feedback on the simulation results and therefore on the model precision. The scattering of the simulation results due to minimum and maximum values of the model parameters for a representative extraction experiment are assessed in the following. The mean value as well as the minimum and the maximum of the individual parameter are listed in Table 4.

Table 4. Parameters for the sensitivity analysis.

\begin{tabular}{cccccc}
\hline Parameter & Min. & Mean & Max. & Deviation & Origin \\
\hline $\mathrm{q}$ & 0.0010237 & 0.00105 & 0.001076 & $\pm 2.5 \%$ & Error propagation \\
$\mathrm{a}$ & 0.117 & 0.13 & 0.143 & $\pm 10 \%$ & Error propagation and reproducibility \\
$\mathrm{V}$ & $0.98 \mathrm{~mL} / \mathrm{min}$ & $1 \mathrm{~mL} / \mathrm{min}$ & $1.02 \mathrm{~mL} / \mathrm{min}$ & $\pm 2 \%$ & Data sheet \\
$\mathrm{m}$ & $18.26 \mathrm{~g}$ & $18.35 \mathrm{~g}$ & $18.44 \mathrm{~g}$ & $\pm 0.5 \%$ & Error propagation \\
$\mathrm{K}_{\mathrm{L}}$ & 67.5 & 75 & 82.5 & $\pm 10 \%$ & Error propagation and reproducibility \\
$\mathrm{d}$ & $800 \mu \mathrm{m}$ & $900 \mu \mathrm{m}$ & $1000 \mu \mathrm{m}$ & $\pm 100 \mu \mathrm{m}$ & Mesh space of sieves \\
\hline
\end{tabular}

The simulation results as well as experimental values are given in Figure 7A. For each simulation, only one parameter has been changed, the remaining parameters remain at their mean value. The experimentally determined extracted mass has a relative deviation of $\pm 4.26 \%$ including reproducibility and error propagation (Figure 7B). The greatest influences on the extracted mass have the initial overall amount and the mean particle diameter. The first parameter leads to a higher or respectively lower loading of the plant material. The particle diameter leads to a faster or respectively slower extraction due to the changing accessibility of the target component. An intermediate effect has the capacity factor and the initial plant mass. Hardly any deviation in the simulation results is referred to the Langmuir-coefficient and the volume flow. None of these parameter intervals leads to a deviation that is more than the experimental error, thus the experimental parameter determination is precise enough in that case and therefore the model is adequate. 

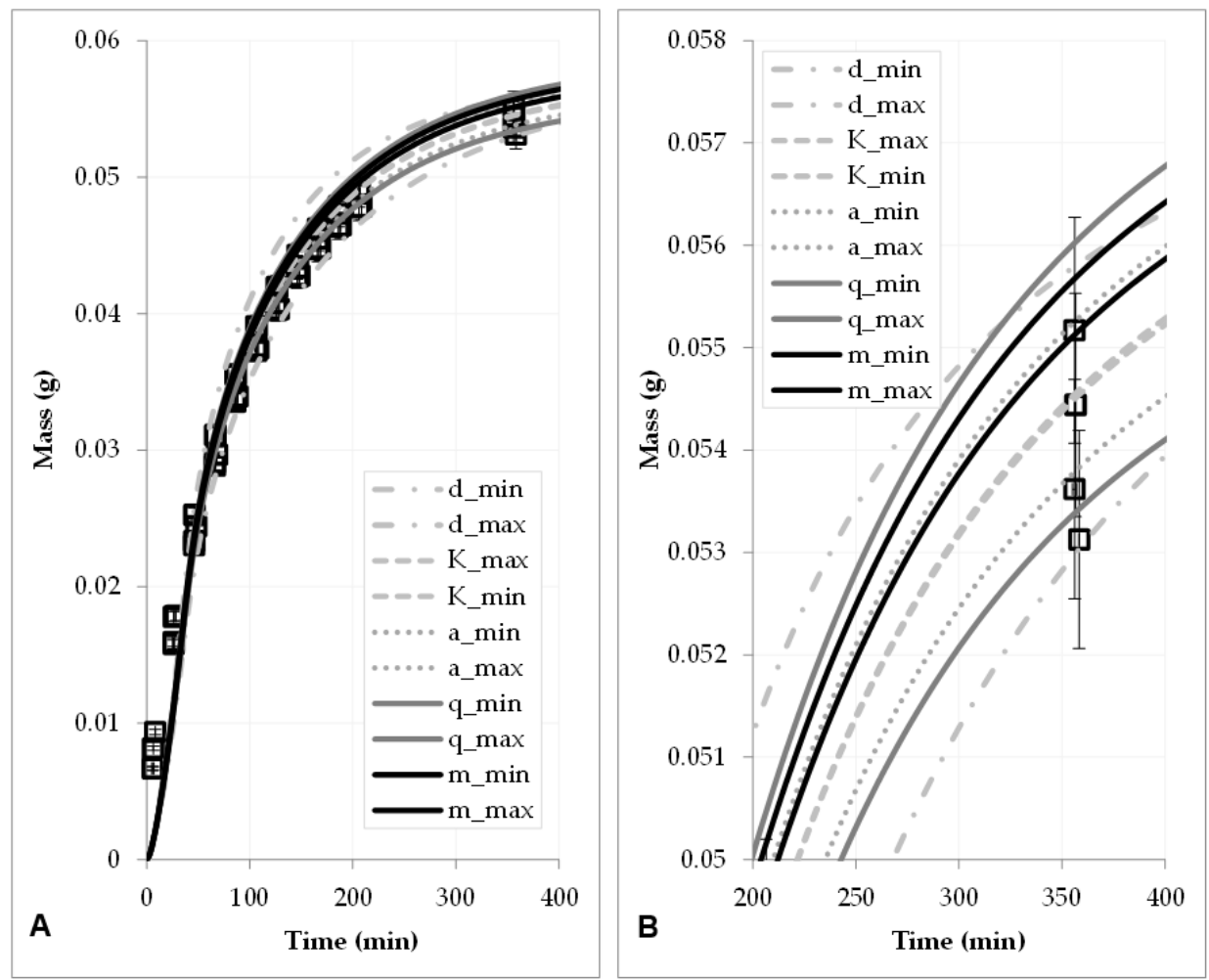

Figure 7. Sensitivity analysis one-parameter-at-a-time. (A) whole extraction; (B) zoom to the last data point (highest mass of extracted components).

\subsection{Statistical Evaluation}

The previous one-parameter-at-a-time study showed that the simulation results vary below the experimental error. To evaluate the resulting precision of the simulation results, due to random parameter combinations, the parameters were mixed by the rules of DoE, resulting in 64 individual simulation runs around one point of operation. The results are given in Figure 8.

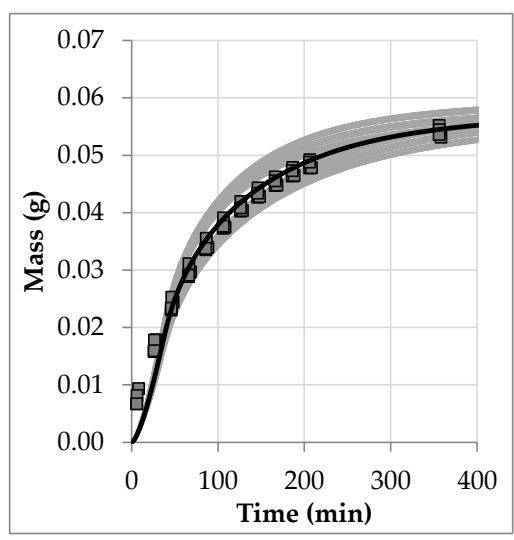

Figure 8. Sensitivity analysis, DoE. 


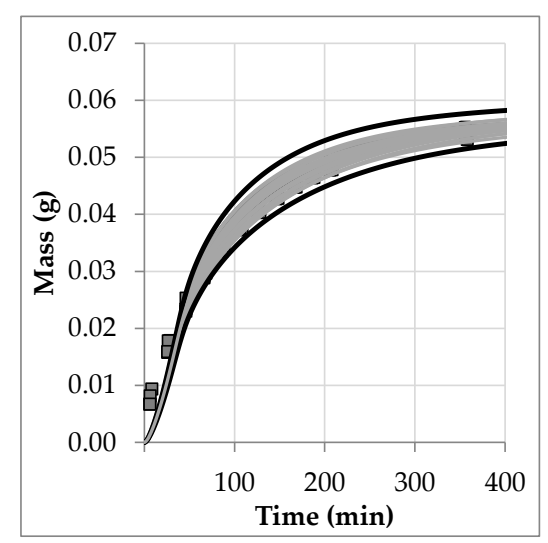

Figure 9. Monte Carlo-based sensitivity analysis; extremes drawn in black from DoE (Figure 8).

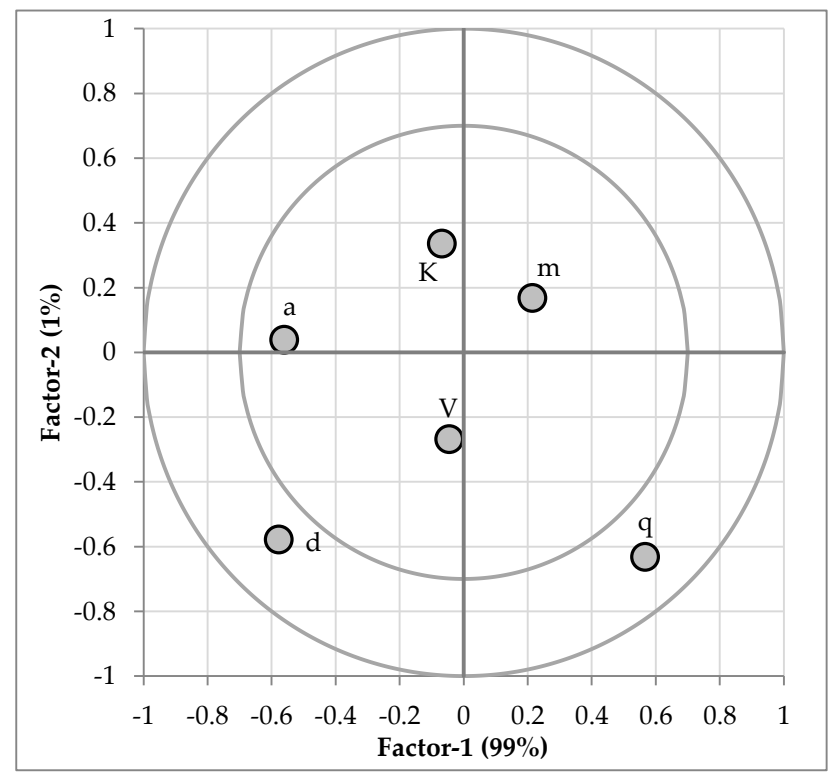

Figure 10. PLS correlations loadings plot.

Result: The deviation is $\pm 4.5 \%$ and therefore only about $5 \%$ above the experimental error. The error of the modelling and simulation is definitely in the same order of magnitude as the experimental extraction data. This shows that the concept of physico-chemical modelling and experimental model parameter determination is valid and precise enough for the prediction of experimental extraction curves. The DoE plan consists of the mean value and the individual minima and maxima of the respective parameter. Highly non-linear influences are therefore not observed. To fill this gap, either a statistical plan including more factor levels or a Monte Carlo simulation with a random distribution of the investigated parameters serves for closing this gap. Both are equally applicable. In that specific case, the effects of the parameters on the simulation results is linear and an additional Monte Carlo simulation does not result in higher or lower envelopes as the initial DoE-plan did, as shown in Figure 9. The application of Monte Carlo simulations has already been shown in [110].

For further statistical analysis, a PLS regression was calculated. The correlation loadings plot is shown in Figure 10. Only one PLS factor is capable of describing $99 \%$ of the data set taken from the DoE plan. The mean particle diameter $d$ and the loading $q$ behave reciprocal. Both, a small mean particle diameter and a high loading lead to a high mass of extracted component at a fixed time. These two parameters contribute significantly to the first principal component of the PLS model. 
The two equilibrium parameters $\mathrm{K}$ and a lead to a high mass of extracted components if they have their smallest values, hence the equilibrium limitation in the system is small.

The plant mass $\mathrm{m}$ is positively correlated to the loading q. Consequently, a high mass leads to a high amount of extracted components. The flux V has nearly no influence on the first PLS factor and can be regarded as not significant. Result: The correlations loadings plot shows that the implemented equations, i.e., the modelling depth of a verified model, behave in a physically consistent way. It also indicates that the measurement precisions of the overall amount and the mean particle diameter have the largest impacts on the simulation results. That supports the results shown in Figure 7.

The same result is obtained by the evaluation of the statistical plan. The resulting main effects are shown in Figure 11. The statistical evaluation shows the same results as the PLS model. The loading q and the mass $\mathrm{m}$ are positively correlated to the extracted mass. The equilibrium parameters a and $\mathrm{K}$ are negatively correlated to the mass, as well as the mean particle diameter $\mathrm{d}$. The flux $\mathrm{V}$ has nearly no influence on the extraction, in that case.

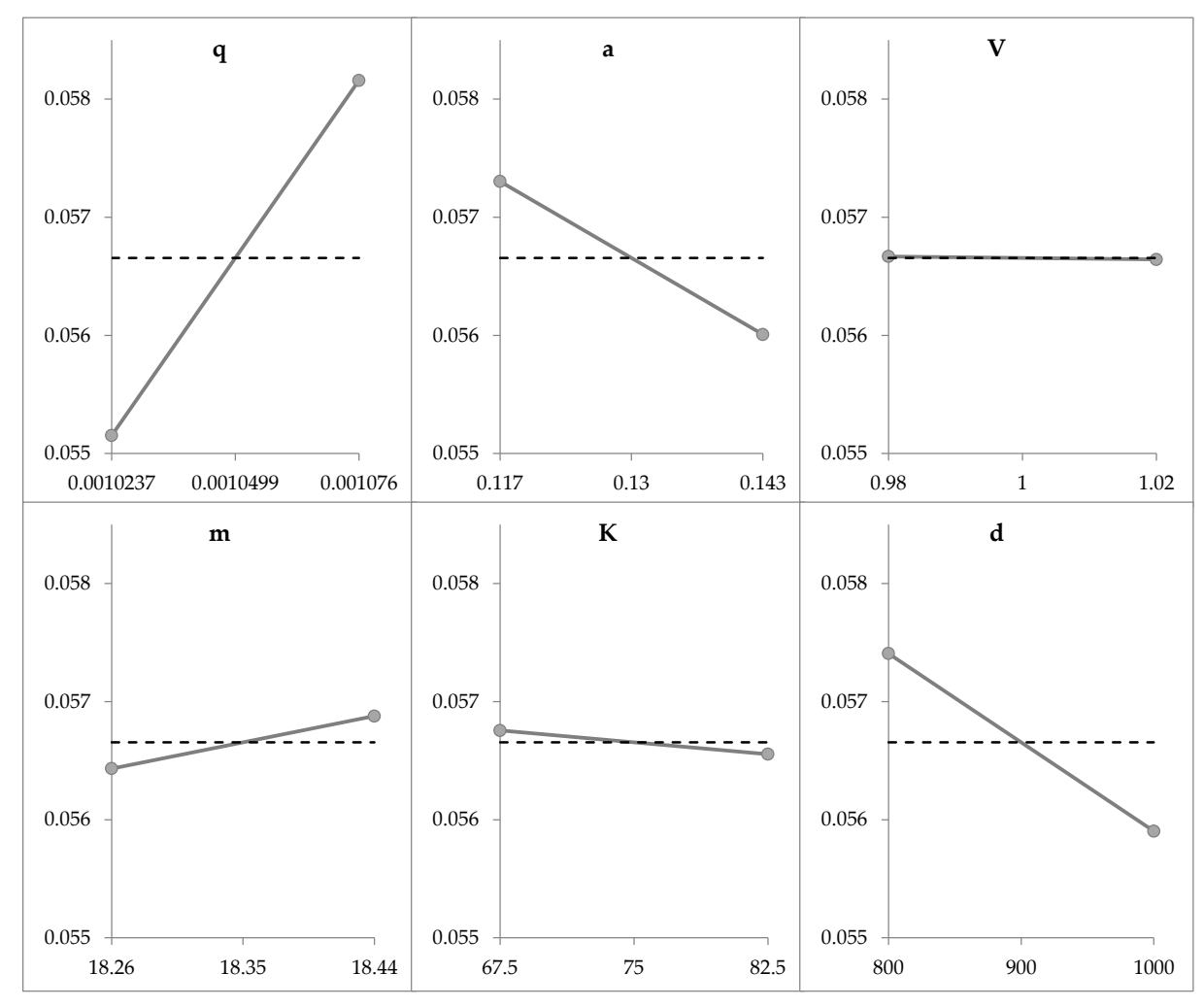

Figure 11. PLS correlations loadings plot.

\section{Conclusions and Discussion}

In order to evaluate the proposed approach as a consistent method with clear quantitative decision criteria based on distinctly defined work plan steps, efforts and benefits have to be discussed.

\subsection{Effort Analysis}

Figure 12 shows a schedule for a complete parameter determination, which is to be handled by one single person with the appropriate equipment. The actual working time is colored in black, the times during which the experiment does not need to be supervised are dark gray, while light gray is the time in which the analysis takes place. 


\begin{tabular}{|c|c|c|c|c|c|c|c|c|}
\hline & Day 1 & Day 2 & Day 3 & Day 4 & Day 5 & Day 6 & Day 7 & Day 8 \\
\hline Experiment & & & & & & & & \\
\hline Solventscreening & & & & & & & & \\
\hline 3.2. Equilibrium & & & & & & & & \\
\hline 3.1. Overall amount & & & & & & & & \\
\hline
\end{tabular}

Figure 12. Schedule of the parameter determination process.

- A complete parameter determination with each experiment being run three times, takes about eight working days;

- To determine all parameters, only about $150 \mathrm{~g}$ of plant material and about $8 \mathrm{~L}$ of solvent are consumed.

If a statistical test plan is used instead of model parameter determination and simulation, one percolation can be carried out daily with the same equipment. Even with only three parameters and one center point as a triplicate, a full-factorial experimental design results in 11 experiments, which together have a much lower information density than the shown path of model parameter determination and proven accurate and precise modelling. The model-based approach is therefore to be preferred in any case especially since with increasing experience the results can be very quickly checked for plausibility or can be transferred to other material systems.

\subsection{Modelling in Modern Process Engineering}

The modern approach for process development and quality assessment Quality-by-Design (QbD) is increasingly widespread, as demanded by regulatory authorities [15]. The idea is to define a design space of operating parameters in which the product always fulfils given quality attributes. This leads to multi-parameter optimizations and a significant experimental effort. Small-scale models or rather physico chemical-process models are capable of filling this gap in terms of model-assisted process design [13], as indicated in Figure 13.

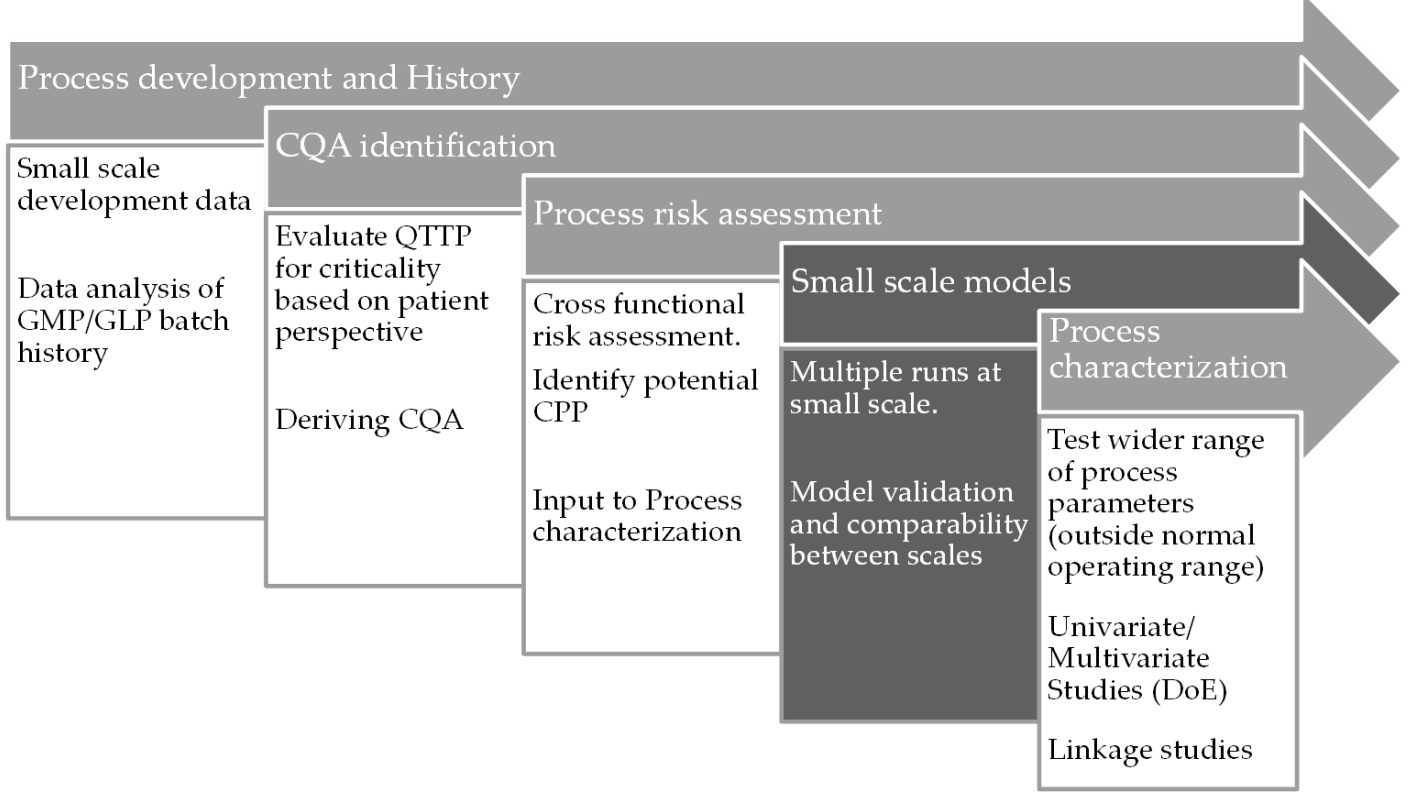

Figure 13. Missing link in process development [13]. 
As explained before, process models are more efficient than experimental scale-down models, but they are only of any use if they are quantitatively distinctly proven to be valid, accurate, and precise, as proposed before, to base any relevant approval or investment decisions on.

For small- and medium-sized enterprises (SMEs) or start-up companies that have never operated on a pilot or manufacturing scale, it is impossible to establish valid experimental scale-down models due to the lack of knowledge, data, and experience how they should correctly scale down in their laboratory. This would partly be overcome by the process modelling approach and enable the activities of such innovative companies towards regulatory approval and fully integrated manufacturing.

\subsection{Workflow}

In order to become a routine method even in small and medium companies, a clear and general workflow of model setup, implementation, verification, and validation with regard to accuracy, e.g., modelling depth and precision, is needed. Such a workflow is proposed as a final conclusion in Figure 14, including relevant tools and decision criteria for every task and evaluation to be performed.

At first, a model task has to be defined. Afterwards, a conceptual model is derived and implemented. The first decision criterion serves for model verification. Here, magnitude of characteristic numbers Reynold, Péclet, Sherwood, Schmidt, have to be in the same magnitude as literature data. The simulation of simplified case studies with known data and outcome serves for further verification. The second decision criterion proves accuracy, whether identical effects are similar significant or not between simulation and reality.

Afterwards, the third decision criterion for model precision is approved, whether the magnitudes of the error bars of modelling errors are smaller than the experimental ones. A DoE-based approach is used here to ensure the maximum degree of information whilst maintaining low efforts and time. To take into account highly non-linear behavior of different parameters, additional Monte Carlo simulations with equally distributed parameters can be done. Twenty to thirty simulations serve to ensure about $95 \%$ probability and $200-300$ simulations for $99 \%$ probability [111]. The DoE-based approach gains identical results at fewer efforts, utilizing only the upper and lower limit of the parameter range. Nevertheless, Monte-Carlo simulations taking into account a distinct parameter distribution, do deliver an additional probability distribution of the results. This is especially useful to rate the chance for outliers and failures during operation. Therefore, the advice generated is to apply DoE at first with only extreme values, than rise the factor level and finally enlarge the simulation runs if needed to Monte-Carlo studies.

The final decision criteria is based on the comparison of field experiments, that are independent and not any part of the experimental model parameter determination setup, which needs at first to be proven to consistency by data reconciliation methods. Such consistent data sets are analyzed due to targets values (yield, purity etc.), parameter range and their sensitivity with regards to analogues simulation data setups. If yield, purity, space-time-yield, specific auxiliary/energy amount, and the slope of parameter interactions on them as well as identical quadrant position of parameter at identical magnitude of correlation coefficients in the PLS regression are coincident, then the model is distinctly quantitative proven to be valid for its at first defined task and application.

It is shown that a model-based process design can be successfully implemented. A corresponding workflow has been designed for the case of liquid-solid extraction. Opportunity is available for expansion to other unit operations and combinations thereof. 


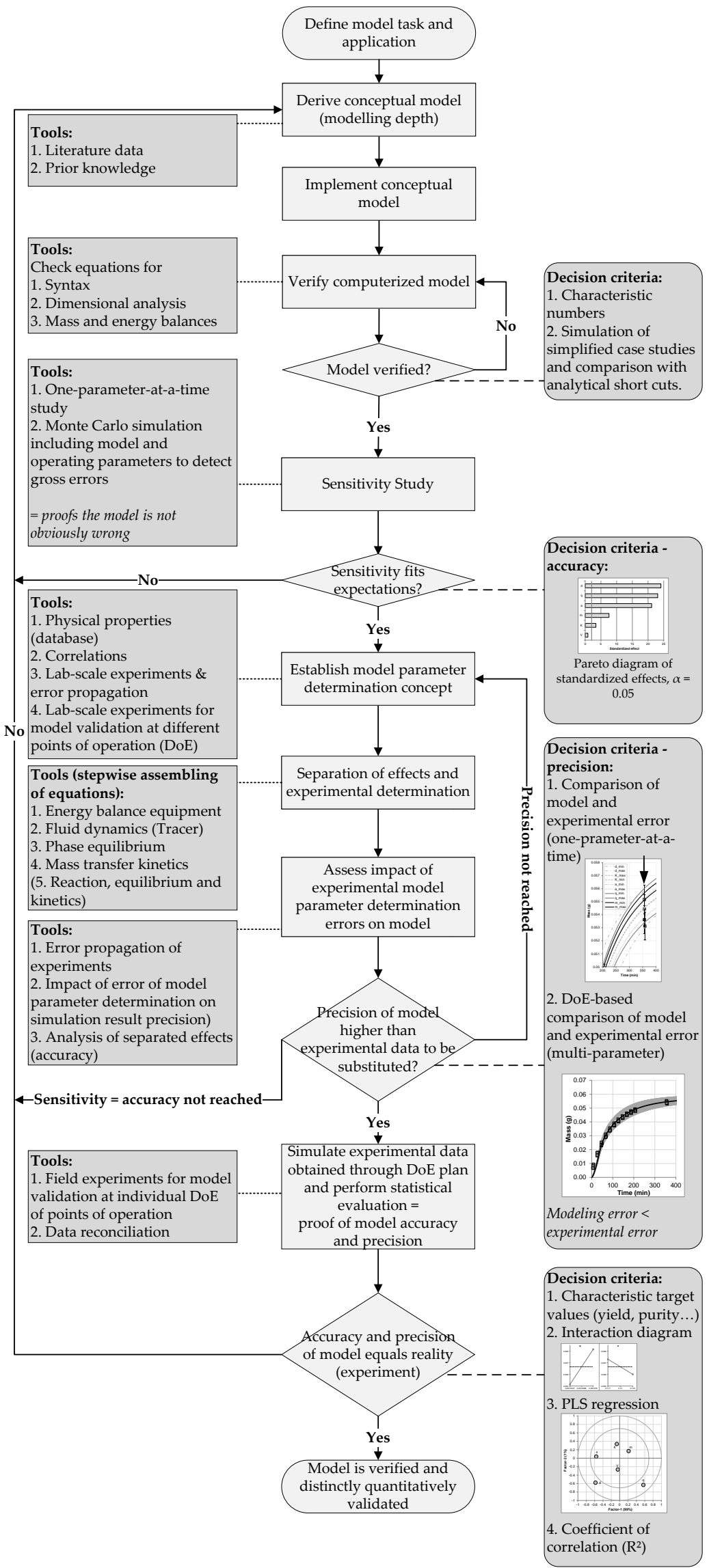

Figure 14. Workflow of process modelling and simulation. 
Author Contributions: M.S. developed the process model and wrote the paper. L.U. contributed to statistical evaluation and visualization. J.S. was responsible for conception and supervision.

Acknowledgments: The authors would like to thank Reinhard Ditz/formerly Merck KGaA, Darmstadt for paper revision and fruitful discussions as well as the experienced ITVP laboratory team. Especially, the lecturers of FAH Bonn and PDA Berlin organized trainings and education courses annually in Clausthal are acknowledged.

Conflicts of Interest: The authors declare no conflict of interest.

\section{Symbols and Abbreviations}

ap Specific surface area, $1 / \mathrm{m}$

$\mathrm{c}_{\mathrm{L}} \quad$ Concentration in the liquid phase, $\mathrm{kg} / \mathrm{m}^{3}$

$\mathrm{c}_{\mathrm{P}} \quad$ Concentration in the porous particle, $\mathrm{kg} / \mathrm{m}^{3}$

$\mathrm{D}_{\mathrm{ax}} \quad$ Axial dispersion coefficient, $\mathrm{m} / \mathrm{s}^{2}$

$D_{\text {eff }}$ Effective diffusion coefficient, $\mathrm{m}^{2} / \mathrm{s}$

DPF Distributed plug flow

$\mathrm{K}_{\mathrm{L}} \quad$ Equilibrium constant, $\mathrm{m}^{3} / \mathrm{kg}$

$\mathrm{k}_{\mathrm{f}} \quad$ Mass transport coefficient, $\mathrm{m} / \mathrm{s}$

Pe Péclet number

PEF Pulsed electrical field

PF Plug flow

PLS Partial Least Square Regression

q Loading, $\mathrm{kg} / \mathrm{m}^{3}$

$\mathrm{q}_{\max }$ Maximum Loading, $\mathrm{kg} / \mathrm{m}^{3}$

Re Reynolds number

$\mathrm{r} \quad$ Radius, $\mathrm{m}$

Sc Schmidt number

Sh Sherwood number

SME Small and medium-sized enterprise

STR Stirred tank reactor

$\mathrm{t}$ Time, $\mathrm{s}$

$\mathrm{u}_{\mathrm{z}} \quad$ Superficial velocity, $\mathrm{m} / \mathrm{s}$

$\mathrm{V} \quad$ Volume flow, $\mathrm{m}^{3} / \mathrm{s}$

$\mathrm{z} \quad$ Coordinate in axial direction, $\mathrm{m}$

$\varepsilon \quad$ Voids fraction, -

$\rho \quad$ Density, $\mathrm{kg} / \mathrm{m}^{3}$

\section{References}

1. Kennedy, R.C.; Xiang, X.; Madey, G.R.; Cosimano, T.F. Verification and Validation of Scientific and Economic Models; PROC Agent: Chicago, IL, USA, 2005.

2. Oreskes, N.; Shrader-Frechette, K.; Belitz, K. Verification, validation, and confirmation of numerical models in the Earth sciences. Science 1994, 263, 641-646. [CrossRef] [PubMed]

3. Ni, D.; Leonard, J.; Guin, A.; Williams, B. Systematic Approach for Validating Traffic Simulation Models. Transp. Res. Rec. 2004, 1876, 20-31. [CrossRef]

4. Schleisinger, S.; Crosbie, R.E.; Gagné, R.E. Terminology for model credibility. Simulation 1979, 32, $103-104$. [CrossRef]

5. Jain, S. Modeling and Analysis for Semiconductor Manufacturing. In Proceedings of the 2011 Winter Simulation Conference, Phoenix, AZ, USA, 11-14 December 2011.

6. Schuler, H. Prozeßsimulation; Vancouver Coastal Health: Weinheim, Germany, 1995.

7. Strube, J. Prädiktive Modellierung von Trennverfahren. Chem. Ing. Tech. 2012, 84, 867. [CrossRef]

8. Dechema. Roadmap Chemical Reaction Engineering: An Initiative of the ProcessNet Subject Division Chemical Reaction Engineering, 2nd ed.; Gesellschaft für Chemische Technik und Biotechnologie: Frankfurt, Germany, 2017. 
9. Ditz, R.; Gerard, D.; Hagels, H.; Igl, N.; Schäffler, M.; Schulz, H.; Stürtz, M.; Tegtmeier, M.; Treutwein, J.; Strube, J.; et al. Phytoextracts. Proposal towards a New Comprehensive Research Focus; Dechema: Frankfurt, Germany, 2017.

10. Dechema. Empfehlungen für Grundständige Studiengänge Biotechnologie mit Naturwissenschaftlichem und Mit Verfahrenstechnischem Schwerpunkt; Dechema: Frankfurt, Germany, 2017.

11. Dechema. Prozessintensivierung: Eine Standortbestimmung; Dechema: Frankfurt, Germany, 2008.

12. Kreysa, G.; Marquardt, R. Biotechnologie 2020; Dechema: Frankfurt, Germany, 2005.

13. Uhlenbrock, L.; Sixt, M.; Strube, J. Quality-by-Design (QbD) process evaluation for phytopharmaceuticals on the example of 10-deacetylbaccatin III from yew. Resource 2017, 3, 137-143. [CrossRef]

14. Food and Drug Administration. Guidance for Industry: PAT-A Framework for Innovative Pharmaceutical Development, Manufacturing, and Quality Assurance; Food and Drug Administration: Silver Spring, MD, USA, 2004.

15. Food and Drug Administration. Guidance for Industry: Q9 Quality Risk Management; Food and Drug Administration: Silver Spring, MD, USA, 2006.

16. Kaßing, M. Process Development for Plant-Based Extract Production; Shaker: Aachen, Germany, 2012.

17. Kaßing, M.; Jenelten, U.; Schenk, J.; Hänsch, R.; Strube, J. Combination of Rigorous and Statistical Modeling for Process Development of Plant-Based Extractions Based on Mass Balances and Biological Aspects. Chem. Eng. Technol. 2012, 35, 109-132. [CrossRef]

18. Both, S.; Eggersglüß, J.; Lehnberger, A.; Schulz, T.; Schulze, T.; Strube, J. Optimizing Established Processes like Sugar Extraction from Sugar Beets-Design of Experiments versus Physicochemical Modeling. Chem. Eng. Technol. 2013, 36, 2125-2136. [CrossRef]

19. Both, S. Systematische Verfahrensentwicklung für Pflanzlich Basierte Produkte im Regulatorischen Umfeld; Shaker: Aachen, Germany, 2015.

20. Both, S.; Chemat, F.; Strube, J. Extraction of polyphenols from black tea-Conventional and ultrasound assisted extraction. Ultrason. Sonochem. 2014, 21, 1030-1034. [CrossRef] [PubMed]

21. Both, S.; Koudous, I.; Jenelten, U.; Strube, J. Model-based equipment-design for plant-based extraction processes-Considering botanic and thermodynamic aspects. C. R. Chim. 2014, 17, 187-196. [CrossRef]

22. Koudous, I. Stoffdatenbasierte Verfahrensentwicklung zur Isolierung von Wertstoffen aus Pflanzenextrakten; Shaker: Herzogenrath, Germany, 2017.

23. Sixt, M.; Koudous, I.; Strube, J. Process design for integration of extraction, purification and formulation with alternative solvent concepts. C. R. Chim. 2016, 19, 733-748. [CrossRef]

24. Sixt, M.; Strube, J. Systematic and Model-Assisted Evaluation of Solvent Based- or Pressurized Hot Water Extraction for the Extraction of Artemisinin from Artemisia annua L. Processes 2017, 5, 86. [CrossRef]

25. Sixt, M.; Strube, J. Pressurized hot water extraction of 10 -deacetylbaccatin III from yew for industrial application. Resource 2017, 3, 177-186. [CrossRef]

26. Sattler, K. Thermische Trennverfahren: Grundlagen, Auslegung, Apparate; Wiley-VCH: Weinheim, Germany, 2001.

27. Chémat, F.; Strube, J. Green Extraction of Natural Products. Theory and Practice; Wiley-VCH Verlag: Weinheim, Germany, 2015.

28. Kaßing, M.; Jenelten, U.; Schenk, J.; Strube, J. A New Approach for Process Development of Plant-Based Extraction Processes. Chem. Eng. Technol. 2010, 33, 377-387. [CrossRef]

29. Levenspiel, O. Chemical Reaction Engineering, 3rd ed.; Wiley: New York, NY, USA, 1999.

30. Sovová, $\mathrm{H}$. Rate of the vegetable oil extraction with supercritical $\mathrm{CO}_{2}-\mathrm{I}$. Modelling of extraction curves. Chem. Eng. Sci. 1994, 49, 409-414. [CrossRef]

31. Sovová, H. Mathematical model for supercritical fluid extraction of natural products and extraction curve evaluation. J. Supercrit. Fluids 2005, 33, 35-52. [CrossRef]

32. Akgün, M.; Akgün, N.A.; Dinçer, S. Extraction and Modeling of Lavender Flower Essential Oil Using Supercritical Carbon Dioxide. Ind. Eng. Chem. Res. 2000, 39, 473-477. [CrossRef]

33. Al-Jabari, M. Modeling analytical tests of supercritical fluid extraction from solids with langmuir kinetics. Chem. Eng. Commun. 2003, 190, 1620-1640. [CrossRef]

34. Bulley, N.R.; Fattori, M.; Meisen, A.; Moyls, L. Supercritical fluid extraction of vegetable oil seeds. J. Am. Oil Chem. Soc. 1984, 61, 1362-1365. [CrossRef]

35. Cacace, J.E.; Mazza, G. Mass transfer process during extraction of phenolic compounds from milled berries. J. Food Eng. 2003, 59, 379-389. [CrossRef] 
36. Carrín, M.E.; Crapiste, G.H. Mathematical modeling of vegetable oil-solvent extraction in a multistage horizontal extractor. J. Food Eng. 2008, 85, 418-425. [CrossRef]

37. Catchpole, O.J.; Grey, J.B.; Smallfield, B.M. Near-critical extraction of sage, celery, and coriander seed. J. Supercrit. Fluids 1996, 9, 273-279. [CrossRef]

38. Chalermchat, Y.; Fincan, M.; Dejmek, P. Pulsed electric field treatment for solid-liquid extraction of red beetroot pigment: Mathematical modelling of mass transfer. J. Food Eng. 2004, 64, 229-236. [CrossRef]

39. Chia, S.L.; Sulaiman, R.; Boo, H.C.; Muhammad, K.; Umanan, F.; Chong, G.H. Modeling of Rice Bran Oil Yield and Bioactive Compounds Obtained Using Subcritical Carbon Dioxide Soxhlet Extraction (SCDS). Ind. Eng. Chem. Res. 2015, 54, 8546-8553. [CrossRef]

40. Cocero, M.J.; García, J. Mathematical model of supercritical extraction applied to oil seed extraction by $\mathrm{CO}_{2}$ + saturated alcohol-I. Desorption model. J. Supercrit. Fluids 2001, 20, 229-243. [CrossRef]

41. De França, L.F.; Meireles, M.A.A. Modeling the extraction of carotene and lipids from pressed palm oil (Elaes guineensis) fibers using supercritical $\mathrm{CO}_{2}$. J. Supercrit. Fluids 2000, 18, 35-47. [CrossRef]

42. Del Valle, J.M.; Napolitano, P.; Fuentes, N. Estimation of Relevant Mass Transfer Parameters for the Extraction of Packed Substrate Beds Using Supercritical Fluids. Ind. Eng. Chem. Res. 2000, 39, 4720-4728. [CrossRef]

43. Del Valle, J.M.; Jiménez, M.; Napolitano, P.; Zetzl, C.; Brunner, G. Supercritical carbon dioxide extraction of pelletized Jalapeño peppers. J. Sci. Food Agric. 2003, 83, 550-556. [CrossRef]

44. Del Valle, J.M.; de la Fuente Juan, C.; Cardarelli, D.A. Contributions to supercritical extraction of vegetable substrates in Latin America. J. Food Eng. 2005, 67, 35-57. [CrossRef]

45. Del Valle, J.M.; de la Fuente Juan, C. Supercritical $\mathrm{CO}_{2}$ extraction of oilseeds: Review of kinetic and equilibrium models. Crit. Rev. Food. Sci. Nutr. 2006, 46, 131-160. [CrossRef] [PubMed]

46. Diankov, S.; Simeonov, E.; Tomova, K. Modelling of Multistage Extraction Kinetics for Nicotiana tabacum L.-Water System. J. Univ. Chem. Technol. Metall. 2008, 43, 119-124.

47. Egorov, A.G.; Salamatin, A.A. Bidisperse Shrinking Core Model for Supercritical Fluid Extraction. Chem. Eng. Technol. 2015, 38, 1203-1211. [CrossRef]

48. Espinoza-Pérez, J.D.; Vargas, A.; Robles-Olvera, V.J.; Rodríguez-Jimenes, G.C.; Garcia-Alvarado, M.A. Mathematical modeling of caffeine kinetic during solid-liquid extraction of coffee beans. J. Food Eng. 2007, 81, 72-78. [CrossRef]

49. Esquível, M.M.; Bernardo-Gil, M.G.; King, M.B. Mathematical models for supercritical extraction of olive husk oil. J. Supercrit. Fluids 1999, 16, 43-58. [CrossRef]

50. Ferreira, S.R.S.; Meireles, M.A.A. Modeling the supercritical fluid extraction of black pepper (Piper nigrum L.) essential oil. J. Food Eng. 2002, 54, 263-269. [CrossRef]

51. Fiori, L.; Calcagno, D.; Costa, P. Sensitivity analysis and operative conditions of a supercritical fluid extractor. J. Supercrit. Fluids 2007, 41, 31-42. [CrossRef]

52. Fiori, L.; Basso, D.; Costa, P. Seed oil supercritical extraction: Particle size distribution of the milled seeds and modeling. J. Supercrit. Fluids 2008, 47, 174-181. [CrossRef]

53. Fiori, L.; Basso, D.; Costa, P. Supercritical extraction kinetics of seed oil: A new model bridging the 'broken and intact cells' and the 'shrinking-core' models. J. Supercrit. Fluids 2009, 48, 131-138. [CrossRef]

54. Goodarznia, I.; Eikani, M.H. Supercritical carbon dioxide extraction of essential oils. Chem. Eng. Sci. 1998, 53, 1387-1395. [CrossRef]

55. Goto, M.; Smith, J.M.; McCoy, B.J. Kinetics and mass transfer for supercritical fluid extraction of wood. Ind. Eng. Chem. Res. 1990, 29, 282-289. [CrossRef]

56. Goto, M.; Sato, M.; Hirose, T. Extraction of Peppermint Oil by Supercritical Carbon Dioxide. J. Chem. Eng. Jpn. 1993, 26, 401-407. [CrossRef]

57. Goto, M.; Roy, B.C.; Hirose, T. Shrinking-core leaching model for supercritical-fluid extraction. J. Supercrit. Fluids 1996, 9, 128-133. [CrossRef]

58. Guerrero, M.S.; Torres, J.S.; Nunez, M.J. Extraction of polyphenols from white distilled grape pomace: Optimization and modelling. Bioresour. Technol. 2008, 99, 1311-1318. [CrossRef] [PubMed]

59. Ji, J.-B.; Lu, X.-H.; Cai, M.-Q.; Xu, Z.-C. Improvement of leaching process of Geniposide with ultrasound. Ultrason. Sonochem. 2006, 13, 455-462. [CrossRef] [PubMed]

60. Jokic, S.; Svilovic, S.; Vidovic, S. Modelling the supercritical $\mathrm{CO}_{2}$ extraction kinetics of soybean oil. Croat. J. Food Sci. Technol. 2015, 7, 52-57. [CrossRef] 
61. Kim, K.H.; Hong, J. Desorption kinetic model for supercritical fluid extraction of spearmint leaf oil. Sep. Sci. Technol. 2001, 36, 1437-1450. [CrossRef]

62. Kim, K.H.; Hong, J. A mass transfer model for super- and near-critical $\mathrm{CO}_{2}$ extraction of spearmint leaf oil. Sep. Sci. Technol. 2002, 37, 2271-2288. [CrossRef]

63. Lee, A.K.K.; Bulley, N.R.; Fattori, M.; Meisen, A. Modelling of supercritical carbon dioxide extraction of Canola oilseed in fixed beds. J. Am. Oil Chem. Soc. 1986, 63, 921-925. [CrossRef]

64. López-Padilla, A.; Ruiz-Rodriguez, A.; Reglero, G.; Fornari, T. Supercritical carbon dioxide extraction of Calendula officinalis: Kinetic modeling and scaling up study. J. Supercrit. Fluids 2017, 130, 292-300. [CrossRef]

65. Lucas, S.; Calvo, M.P.; García-Serna, J.; Palencia, C.; Cocero, M.J. Two-parameter model for mass transfer processes between solid matrixes and supercritical fluids: Analytical solution. J. Supercrit. Fluids 2007, 41, 257-266. [CrossRef]

66. Machmudah, S.; Sulaswatty, A.; Sasaki, M.; Goto, M.; Hirose, T. Supercritical $\mathrm{CO}_{2}$ extraction of nutmeg oil: Experiments and modeling. J. Supercrit. Fluids 2006, 39, 30-39. [CrossRef]

67. Macías-Sánchez, M.D.; Serrano, C.M.; Rodríguez, M.R.; Martínez de la Ossa, E. Kinetics of the supercritical fluid extraction of carotenoids from microalgae with $\mathrm{CO}_{2}$ and ethanol as cosolvent. Chem. Eng. J. 2009, 150, 104-113. [CrossRef]

68. Madras, G.; Thibaud, C.; Erkey, C.; Akgerman, A. Modeling of supercritical extraction of organics from solid matrices. AIChE J. 1994, 40, 777-785. [CrossRef]

69. Mantell, C.; Rodríguez, M.; Martínez de la Ossa, E. Semi-batch extraction of anthocyanins from red grape pomace in packed beds: Experimental results and process modelling. Chem. Eng. Sci. 2002, 57, 3831-3838. [CrossRef]

70. Marrone, C.; Poletto, M.; Reverchon, E.; Stassi, A. Almond oil extraction by supercritical $\mathrm{CO}_{2}$ : Experiments and modelling. Chem. Eng. Sci. 1998, 53, 3711-3718. [CrossRef]

71. Martínez, J.; Monteiro, A.R.; Rosa, P.T.V.; Marques, M.O.M.; Meireles, M.A.A. Multicomponent Model to Describe Extraction of Ginger Oleoresin with Supercritical Carbon Dioxide. Ind. Eng. Chem. Res. 2003, 42, 1057-1063. [CrossRef]

72. Nagy, B.; Simándi, B. Effects of particle size distribution, moisture content, and initial oil content on the supercritical fluid extraction of paprika. J. Supercrit. Fluids 2008, 46, 293-298. [CrossRef]

73. Özkal, S.G.; Yener, M.E.; Bayındırlı, L. Mass transfer modeling of apricot kernel oil extraction with supercritical carbon dioxide. J. Supercrit. Fluids 2005, 35, 119-127. [CrossRef]

74. Peker, H.; Srinivasan, M.P.; Smith, J.M.; McCoy, B.J. Caffeine extraction rates from coffee beans with supercritical carbon dioxide. AIChE J. 1992, 38, 761-770. [CrossRef]

75. Perrut, M.; Clavier, J.Y.; Poletto, M.; Reverchon, E. Mathematical Modeling of Sunflower Seed Extraction by Supercritical $\mathrm{CO}_{2}$. Ind. Eng. Chem. Res. 1997, 36, 430-435. [CrossRef]

76. Pinelo, M.; Sineiro, J.; Núñez, M.J. Mass transfer during continuous solid-liquid extraction of antioxidants from grape byproducts. J. Food Eng. 2006, 77, 57-63. [CrossRef]

77. Poletto, M.; Reverchon, E. Comparison of Models for Supercritical Fluid Extraction of Seed and Essential Oils in Relation to the Mass-Transfer Rate. Ind. Eng. Chem. Res. 1996, 35, 3680-3686. [CrossRef]

78. Reis-Vasco, E.M.C.; Coelho, J.A.P.; Palavra, A.M.F.; Marrone, C.; Reverchon, E. Mathematical modelling and simulation of pennyroyal essential oil supercritical extraction. Chem. Eng. Sci. 2000, 55, 2917-2922. [CrossRef]

79. Reverchon, E. Mathematical modeling of supercritical extraction of sage oil. AIChE J. 1996, 42, $1765-1771$. [CrossRef]

80. Reverchon, E.; Marrone, C. Supercritical extraction of clove bud essential oil: Isolation and mathematical modeling. Chem. Eng. Sci. 1997, 52, 3421-3428. [CrossRef]

81. Reverchon, E.; Daghero, J.; Marrone, C.; Mattea, M.; Poletto, M. Supercritical Fractional Extraction of Fennel Seed Oil and Essential Oil: Experiments and Mathematical Modeling. Ind. Eng. Chem. Res. 1999, 38, 3069-3075. [CrossRef]

82. Reverchon, E.; Kaziunas, A.; Marrone, C. Supercritical $\mathrm{CO}_{2}$ extraction of hiprose seed oil: Experiments and mathematical modelling. Chem. Eng. Sci. 2000, 55, 2195-2201. [CrossRef]

83. Reverchon, E.; Marrone, C. Modeling and simulation of the supercritical $\mathrm{CO}_{2}$ extraction of vegetable oils. J. Supercrit. Fluids 2001, 19, 161-175. [CrossRef] 
84. Rosa, R.H.; von Atzingen, G.V.; Belandria, V.; Oliveira, A.L.; Bostyn, S.; Rabi, J.A. Lattice Boltzmann simulation of cafestol and kahweol extraction from green coffee beans in high-pressure system. J. Food Eng. 2016, 176, 88-96. [CrossRef]

85. Roy, B.C.; Goto, M.; Hirose, T. Extraction of Ginger Oil with Supercritical Carbon Dioxide: Experiments and Modeling. Ind. Eng. Chem. Res. 1996, 35, 607-612. [CrossRef]

86. Salamatin, A.A. Detection of Microscale Mass-Transport Regimes in Supercritical Fluid Extraction. Chem. Eng. Technol. 2017, 40, 829-837. [CrossRef]

87. Seikova, I.; Simeonov, E. Determination of Solid Deformation Effect on the Effective Diffusivity during Extraction from Plants. Sep. Sci. Technol. 2003, 38, 3713-3729. [CrossRef]

88. Seikova, I.; Simeonov, E.; Ivanova, E. Protein leaching from tomato seed-Experimental kinetics and prediction of effective diffusivity. J. Food Eng. 2004, 61, 165-171. [CrossRef]

89. Simeonov, E.; Tsibranska, I.; Minchev, A. Solid-liquid extraction from plants-Experimental kinetics and modelling. Chem. Eng. J. 1999, 73, 255-259. [CrossRef]

90. Simeonov, E.; Seikova, I.; Pentchev, I.; Mintchev, A. Modeling of a Screw Solid-Liquid Extractor through Concentration Evolution Experiments. Ind. Eng. Chem. Res. 2003, 42, 1433-1438. [CrossRef]

91. Simeonov, E.; Koleva, V. Solid-Liquid Extraction from Roots of Geranium sanquineum L. J. Univ. Chem. Technol. Metall. 2008, 43, 409-412.

92. Škerget, M.; Knez, Ž. Modelling high pressure extraction processes. Comput. Chem. Eng. 2001, 25, 879-886. [CrossRef]

93. Sovová, H.; Komers, R.; Kučera, J.; Jež, J. Supercritical carbon dioxide extraction of caraway essential oil. Chem. Eng. Sci. 1994, 49, 2499-2505. [CrossRef]

94. Stamenić, M.; Zizovic, I.; Orlović, A.; Skala, D. Mathematical modelling of essential oil SFE on the micro-scale-Classification of plant material. J. Supercrit. Fluids 2008, 46, 285-292. [CrossRef]

95. Št'astová, J.; Jež, J.; Bártlová, M.; Sovová, H. Rate of the vegetable oil extraction with supercritical $\mathrm{CO}_{2}-\mathrm{III}$. Extraction from sea buckthorn. Chem. Eng. Sci. 1996, 51, 4347-4352. [CrossRef]

96. Ndocko Ndocko, E.; Bäcker, W.; Strube, J. Process Design Method for Manufacturing of Natural Compounds and Related Molecules. Sep. Sci. Technol. 2008, 43, 642-670. [CrossRef]

97. DeSouza, A.T.; Benazzi, T.L.; Grings, M.B.; Cabral, V.; Antônio da Silva, E.; Cardozo-Filho, L.; Ceva Antunes, O.A. Supercritical extraction process and phase equilibrium of Candeia (Eremanthus erythropappus) oil using supercritical carbon dioxide. J. Supercrit. Fluids 2008, 47, 182-187. [CrossRef]

98. Veloso, G.O.; Thomas, G.C.; Krioukov, V.G. A mathematical model of extraction in countercurrent crossed flows. Chem. Eng. Process. 2008, 47, 1470-1477. [CrossRef]

99. Winitsorn, A.; Douglas, P.L.; Douglas, S.; Pongampai, S.; Teppaitoon, W. Modeling the extraction of valuable substances from natural plants using solid-liquid extraction. Chem. Eng. Commun. 2008, 195, 1457-1464. [CrossRef]

100. Wu, W.; Hou, Y. Mathematical modeling of extraction of egg yolk oil with supercritical $\mathrm{CO}_{2}$. J. Supercrit. Fluids 2001, 19, 149-159. [CrossRef]

101. Zizovic, I.; Stamenić, M.; Orlović, A.; Skala, D. Supercritical carbon dioxide essential oil extraction of Lamiaceae family species: Mathematical modelling on the micro-scale and process optimization. Chem. Eng. Sci. 2005, 60, 6747-6756. [CrossRef]

102. Zizovic, I.; Stamenić, M.; Orlović, A.; Skala, D. Supercritical carbon dioxide extraction of essential oils from plants with secretory ducts: Mathematical modelling on the micro-scale. J. Supercrit. Fluids 2007, 39, 338-346. [CrossRef]

103. Chung, S.F.; Wen, C.Y. Longitudinal dispersion of liquid flowing through fixed and fluidized beds. AIChE J. 1968, 14, 857-866. [CrossRef]

104. Altenhöner, U.; Meurer, M.; Strube, J.; Schmidt-Traub, H. Parameter estimation for the simulation of liquid chromatography. J. Chromatogr. A 1997, 769, 59-69. [CrossRef]

105. Strube, J.; Altenhöner, U.; Meurer, M.; Schmidt-Traub, H.; Schulte, M. Dynamic simulation of simulated moving-bed chromatographic processes for the optimization of chiral separations. J. Chromatogr. A 1997, 769, 81-92. [CrossRef]

106. Schmidt-Traub, H. Preparative Chromatography, 2nd ed.; Wiley-VCH Verlag: Weinheim, Germany, 2013.

107. Ndocko Ndocko, E.; Ditz, R.; Josch, J.-P.; Strube, J. New Material Design Strategy for Chromatographic Separation Steps in Bio-Recovery and Downstream Processing. Chem. Ing. Tech. 2011, 83, 113-129. [CrossRef] 
108. Baerns, M. Technische Chemie; Wiley-VCH-Verlag: Weinheim, Germany, 2006.

109. Gudi, G.; Krähmer, A.; Koudous, I.; Strube, J.; Schulz, H. Infrared and Raman spectroscopic methods for characterization of Taxus baccata L.-Improved taxane isolation by accelerated quality control and process surveillance. Talanta 2015, 143, 42-49. [CrossRef] [PubMed]

110. Subramanian, G. Biopharmaceutical Production Technology; Wiley-VCH-Verlag: Weinheim, Germany, 2012.

111. Subramani, H.J.; Hidajat, K.; Ray, A.K. Optimization of reactive SMB and Varicol systems. Comput. Chem. Eng. 2003, 27, 1883-1901. [CrossRef]

(C) 2018 by the authors. Licensee MDPI, Basel, Switzerland. This article is an open access article distributed under the terms and conditions of the Creative Commons Attribution (CC BY) license (http:/ / creativecommons.org/licenses/by/4.0/). 